\title{
Allopatric speciation in the flightless Phoberus capensis (Coleoptera: Trogidae) group, with description of two new species
}

\author{
Werner P. Strümpher ${ }^{1,2}$, Catherine L. Sole ${ }^{2}$, Martin H. Villet ${ }^{1} \&$ Clarke H. Scholtz $^{2}$ \\ ${ }^{1}$ Department of Zoology and Entomology, Rhodes University, Grahamstown, 6140, South Africa; ${ }^{2}$ Scarab \\ Research Group, Department of Zoology \& Entomology, University of Pretoria, Private Bag X 20, Hatfield \\ 0028, Pretoria, South Africa
}

Correspondence: Werner P. Strümpher Scarab Research Group, Department of Zoology \& Entomology, University of Pretoria, Private Bag X 20, Hatfield 0028, Pretoria, South Africa.

Running title: Speciation in Phoberus capensis group

Telephone: +27124203754

Fax: +27123625242

Email: wstrumpher@zoology.up.ac.za

\begin{abstract}
The name Phoberus capensis (Scholtz) is applied to a small flightless, keratinophagous beetle endemic to the Cape Floristic Region of South Africa. Its gross distribution stretches from roughly $1000 \mathrm{~km}$ from the Cederberg (S32²4'22" E1904'50") to Grahamstown (S33²0'07" E26³2'50"). The populations are spatially discrete, restricted to relict forests of the southern Cape and disjunct high montane refugia of the Cape Fold Mountains. We test the hypothesis that there is more than one distinct species nested within the name P. capensis. Phylogenetic relationships among populations were inferred using molecular sequence data. The results support three distinct evolutionary lineages, which were also supported by morphological
\end{abstract}


characters. Divergence time estimates suggest Pliocene-Pleistocene diversification. Based on these results, it is suggested that the $P$. capensis lineage experienced climatically-driven allopatric speciation with sheltered Afrotemperate forests and high mountain peaks serving as important refugia in response to climatic ameliorations. The $P$. capensis complex thus represents a speciation process in which flight-restricted populations evolved in close allopatry, possibly as recently as the Pleistocene. Two divergent and geographically distinct lineages are described as novel species: The new species, $P$. disjunctus $\mathrm{sp}$. n. and $P$. herminae sp. n., are illustrated by photographs of habitus and male aedeagi.

\section{Keywords}

Cape Fold Mountains; keratin; Phoberus; relict groups; Scarabaeoidea; southern Africa

\section{Introduction}

The Cape Floristic Region (CFR) of the southern-western Cape region of South Africa is recognised as one of the world's six Floral Kingdoms (Myers et al. 2000; Mucina \& Rutherford 2006; Cowling 2009). The region exhibits exceptional floral diversity and high levels of biotic endemism (Linder 2003, 2005). It is characterised by a Mediterranean (temperate) type climate and a unique sclerophyllous, fire-prone shrubland known as Cape 'fynbos' (Linder 2003, 2005; Galley \& Linder 2006; Mucina \& Rutherford 2006). The development of the drought-resistant (pyrophytic) vegetation of the CFR is attributed to dramatic climate shifts from warm, tropical conditions to drier, more seasonal conditions during the Miocene/Pliocene (Cowling et al. 2009; Dupont et al. 2011; McDonald \& Daniels 2012). Various factors, including the development of the cold Benguela Current along the west coast of southern Africa during the late Miocene (Siesser 1980; Pickford \& Senut 1999), and tectonic uplift during the early Miocene (18 Mya) and the Pliocene (5 Mya), caused 
progressive aridification of the sub-continent. The combination of climate fluctuations, tectonic uplift and marine transgression and regression associated with the Pleistocene glacial cycle resulted in considerable habitat fragmentation, extinction and expansion events within the biome, thus providing an important stimulus for speciation and diversification (Partridge et al. 1999; Linder 2005; Tolley et al. 2006; Cowling et al. 2009). Climatically-driven speciation has been shown for a variety of taxa in the CFR (Tolley et al. 2006; Price et al. 2007, 2010; Swart et al. 2009; Linder et al. 2010; McDonald \& Daniels 2012; Sole et al. 2013).

The CFR is dominated by the ancient Cape Fold Mountains (CFM) which can be divided into several mountain blocks: (1) a single western mountain range running parallel to the Atlantic Ocean coast, and (2) a double mountain range running parallel to the Indian Ocean coast (Linder 2003). The mountain ranges are separated by arid, low-lying valleys and plains, sheltered ravines and deeply incised gorges (Cowling et al. 2009). The CFM consists of highly erosion-resistant sandstone and most of these mountains reach altitudes higher than $1500 \mathrm{~m}$ above sea level, contributing to the heterogeneity of the region. These high mountains act as barriers to maritime moisture moving inland from the Atlantic and Indian Oceans, which has a profound effect on the local climate because seaward-facing slopes are moister and inland plains in the rain shadow of these mountains are very arid (Linder 2003).

The CFR and the CFM specifically provide suitable habitat and refugia for a number of relict flightless Scarabaeoidea (Coleoptera) (Scarabaeidae: Medina \& Scholtz 2005; Sole et al. 2005; Deschodt et al. 2007, 2011; Deschodt \& Scholtz 2008; Sole \& Scholtz 2013; Lucanidae: Endrödy-Younga 1988, Switala et al. 2014; Trogidae: Scholtz 1979, 1980). The flightless species generally occupy the summits, forested palaeo-refugia on the seaward- 
facing slopes and the coastal plains. These cool, temperate environments may have acted as buffer zones and long-term refugia for many organisms in response to the effects of changing climate (Stuckenberg 1962; Endrödy-Younga 1978; Linder \& Vlok 1991; Geldenhuys 1997; Midgley et al. 2001; Daniels et al. 2013).

Figure 1. Map of the distribution of Phoberus capensis (Scholtz), P. disjunctus sp. n., P. herminae sp. n. and $P$ nasutus (Harold). Sample locality numbers follow Table 1.

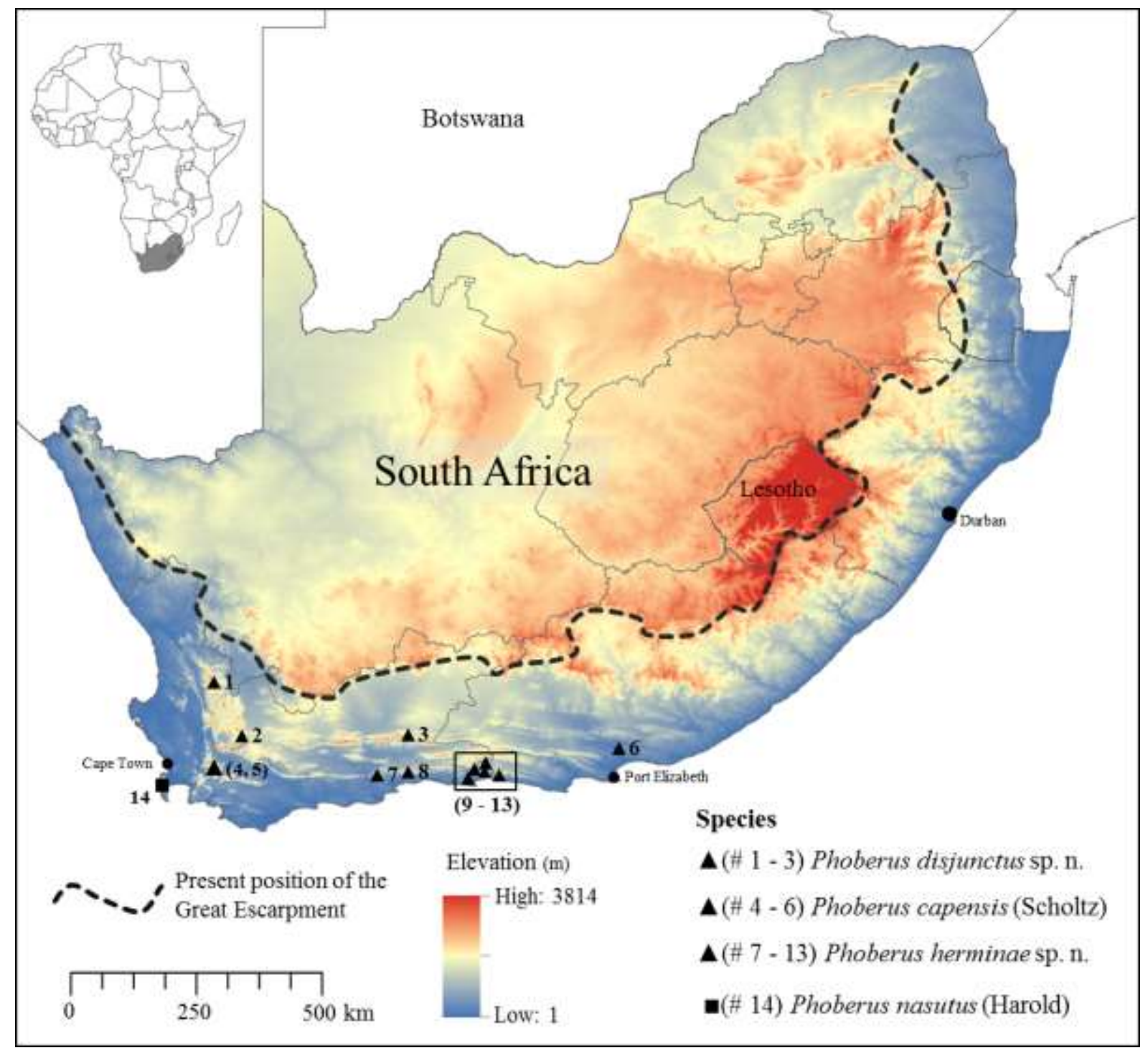

Phoberus capensis (Scholtz) (Scarabaeoidea: Trogidae) is a small (4-7 mm) flightless, keratinophagous beetle endemic to the CFR of South Africa. Its gross distribution stretches roughly $1000 \mathrm{~km}$ from the Cederberg (S32²4'22" E1904'50") to Grahamstown (S33²0'07" 
E26 $\left.32 ' 50^{\prime \prime}\right)$. However, its populations are clearly spatially discrete, restricted to relict forests of the southern Cape and disjunct high montane refugia of the CFM (Fig 1). Its habitat specificity, disjunct population distributions and low vagility (due to flightlessness) make $P$. capensis an ideal species for answering questions regarding speciation and diversification events. In this study we test the hypothesis that there is more than one distinct species nested within what is currently recognised as $P$. capensis. To do this we analyse mitochondrial DNA sequences and also estimate the divergence times and ages of the populations.

\section{Material \& Methods}

Sampling and laboratory protocols

Phoberus capensis was sampled from localities across its known distribution (Table 1and Table A1 in the Appendix). Phoberus nasutus (Harold), the sister species (Strümpher et al., 2014), was used as the outgroup. The latter is restricted to the Cape Peninsula - an isolated mountainous area surrounded by the Atlantic Ocean in the west and the Cape Flats to the east (Macdonald \& Daniels 2012). Collected specimens were deposited at the Department of Zoology and Entomology, University of Pretoria, South Africa (UPSA).

Total genomic DNA was extracted from a leg of each of 53 individuals and partially sequenced for the protein-coding mitochondrial Cytochrome Oxidase I subunit (COI) gene and the mitochondrial 16S small subunit ribosomal RNA (16S) gene. The primer pairs used for amplification and sequencing were COI: C1-J-1718 with TL2-N-3014 (Simon et al. 1994); and 16S: 16sf with 16sr (Orsini et al. 2007). DNA fragments for the two gene regions were amplified using the polymerase chain reaction (PCR) performed in a final volume of $25 \mu 1$ made up of $20 \mathrm{pmol}$ of each primer, Emerald Amp®MAX HS PCRMastermix (Takara Bio Inc., Otsu, Shiga, Japan), and 50-100 ng of genomic DNA template. 
Table 1. Specimens of Phoberus capensis group collected from the Western Cape and Eastern Cape provinces, South Africa.

\begin{tabular}{|c|c|c|c|c|}
\hline$N$ & Sample locality & $\begin{array}{l}\text { Altitude } \\
\text { (m asl) }\end{array}$ & Coordinates & $n$ \\
\hline 1 & Cederberg Mountains & $1547 \mathrm{~m}$ & $\begin{array}{l}\mathrm{S} 32^{\circ} 24^{\prime 22.43 "} \\
\mathrm{E} 19^{\circ} 04^{\prime} 50.37^{\prime \prime}\end{array}$ & 1 \\
\hline 2 & Hexrivier Mountains, Matroosberg & $1880 \mathrm{~m}$ & $\begin{array}{l}\mathrm{S} 33^{\circ} 22^{\prime} 22.23^{\prime \prime} \\
\mathrm{E} 19^{\circ} 39^{\prime} 34.77^{\prime \prime}\end{array}$ & 4 \\
\hline 3 & Swartberg Mountains, Swartberg Pass & $1510 \mathrm{~m}$ & $\begin{array}{l}\mathrm{S} 33^{\circ} 20^{\prime} 59.27^{\prime \prime} \\
\mathrm{E} 22^{\circ} 15^{\prime} 51.90^{\prime \prime}\end{array}$ & 6 \\
\hline 4 & Hottentots-Holland, Sneeukop & $1406 \mathrm{~m}$ & $\begin{array}{l}\mathrm{S} 34^{\circ} 02^{\prime} 21.08^{\prime \prime} \\
\mathrm{E} 18^{\circ} 59^{\prime} 24.94^{\prime \prime}\end{array}$ & 13 \\
\hline 5 & Hottentots-Holland, Moordenaarskop & $940 \mathrm{~m}$ & $\begin{array}{l}\mathrm{S} 34^{\circ} 05^{\prime} 53.12^{\prime \prime} \\
\mathrm{E} 18^{\circ} 57^{\prime} 52.74^{\prime \prime}\end{array}$ & 2 \\
\hline 6 & Grahamstown, Signal Hill & $622 \mathrm{~m}$ & $\begin{array}{l}\mathrm{S} 33^{\circ} 20^{\prime} 07.54^{\prime \prime} \\
\mathrm{E} 26^{\circ} 32^{\prime} 50.23^{\prime \prime}\end{array}$ & 2 \\
\hline 7 & Langeberge, Ruiterbos & $800 \mathrm{~m}$ & $\begin{array}{l}\mathrm{S} 33^{\circ} 52^{\prime} 31.37^{\prime \prime} \\
\mathrm{E} 22^{\circ} 01^{\prime} 22.00^{\prime \prime}\end{array}$ & 3 \\
\hline 8 & Outeniqua Mountains, Outeniqua Pass & $668 \mathrm{~m}$ & $\begin{array}{l}\mathrm{S} 33^{\circ} 54^{\prime} 02.05^{\prime \prime} \\
\mathrm{E} 22^{\circ} 24^{\prime} 04.09^{\prime \prime}\end{array}$ & 3 \\
\hline 9 & Tsitsikama Forest, Nature's Valley & $38 \mathrm{~m}$ & $\begin{array}{l}\mathrm{S} 33^{\circ} 58^{\prime} 02.00^{\prime \prime} \\
\mathrm{E} 23^{\circ} 33^{\prime} 36.80^{\prime \prime}\end{array}$ & 2 \\
\hline 10 & Knysna, Diepwalle Forest & $420 \mathrm{~m}$ & $\begin{array}{l}\mathrm{S} 33^{\circ} 57^{\prime} 40.92^{\prime \prime} \\
\mathrm{E} 23^{\circ} 09^{\prime} 22.79^{\prime \prime}\end{array}$ & 3 \\
\hline 11 & Knysna, Buffalo Valley & $81 \mathrm{~m}$ & $\begin{array}{l}\mathrm{S} 33^{\circ} 59^{\prime} 29.51^{\prime \prime} \\
\mathrm{E} 23^{\circ} 17^{\prime} 55.34^{\prime \prime}\end{array}$ & 4 \\
\hline 12 & Knysna, Harkerville Forest & $276 \mathrm{~m}$ & $\begin{array}{l}\mathrm{S} 34^{\circ} 03^{\prime} 00.53^{\prime \prime} \\
\mathrm{E} 23^{\circ} 12^{\prime} 00.34^{\prime \prime}\end{array}$ & 9 \\
\hline 13 & Stormsrivier & $102 \mathrm{~m}$ & $\begin{array}{l}\mathrm{S} 33^{\circ} 58^{\prime} 18.01^{\prime \prime} \\
\mathrm{E} 23^{\circ} 53^{\prime} 53.00^{\prime \prime}\end{array}$ & 1 \\
\hline 14 & Cape Peninsula, nr Simonstown & $98 \mathrm{~m}$ & $\begin{array}{l}\mathrm{S} 34^{\circ} 13^{\prime} 19.20^{\prime \prime} \\
\mathrm{E} 18^{\circ} 24^{\prime} 38.48^{\prime \prime}\end{array}$ & 3 \\
\hline
\end{tabular}

$N$, population number; $n$, number of individuals collected from each locality.

Thermal cycling parameters for COI comprised an initial denaturation for $90 \mathrm{~s}$ at $95^{\circ} \mathrm{C}$

followed by 35 cycles at $94^{\circ} \mathrm{C}$ for $22 \mathrm{~s}$, annealing at $50^{\circ} \mathrm{C}$ for $30 \mathrm{~s}$ and $72^{\circ} \mathrm{C}$ for $90 \mathrm{~s}$ with a final elongation step at $72^{\circ} \mathrm{C}$ for $1 \mathrm{~min}$; and for $16 \mathrm{~S}$ an initial denaturation at $94^{\circ} \mathrm{C}$ for $90 \mathrm{~s}$ 
followed by 35 cycles at $94^{\circ} \mathrm{C}$ for $60 \mathrm{~s}$, annealing at $48^{\circ} \mathrm{C}$ for $90 \mathrm{~s}$ and $72^{\circ} \mathrm{C}$ for $90 \mathrm{~s}$ with a final elongation step at $72^{\circ} \mathrm{C}$ for $1 \mathrm{~min}$.

Successful amplifications were purified using the NucleoSpin ${ }^{\circledR ~ G e l ~ a n d ~ P C R ~ C l e a n-u p ~ k i t ~}$ (Macherey-Nagel) following the manufacturer's instructions. To obtain DNA sequences, the cycle sequencing reactions were carried out in both directions using the BigDye ${ }^{\circledR}$ Terminator v3.1 Cycle Sequencing kit (Applied Biosystems). Cycle sequencing products were precipitated using a standard sodium acetate/ethanol precipitation protocol. All sequences were viewed, edited and assembled in CLC Bio 5.6 (http://www.clcbio.com/). New sequences were submitted to GenBank (see Tables A2 and A3 in the Appendix).

\section{Alignment}

The sequences were aligned using the program package MAFFT (Katoh \& Toh 2008) with default settings. The alignments for the two gene regions (COI, 16S) were concatenated into a supermatrix using the program FASconCAT version 1.0 (Kück \& Meusemann 2010)

\section{Phylogenetic analysis}

jModel Test (Posada 2008) was used to select the appropriate model of sequence evolution under the Akaike information criterion (Akaike 1974). Phylogenetic trees were inferred using Maximum Parsimony (MP), Bayesian Inference (BI) and Maximum Likelihood (ML) approaches.

A parsimony analysis was implemented in PAUP*4.010b (Swofford 2003) with the following heuristic search setting: all characters were equally weighted and unordered, gaps were treated as missing data and uninformative sites were excluded; starting tree obtained via stepwise addition with random addition of sequences with 10 replicates; branch-swapping = 
tree-bisection-reconnection; initial 'maxtrees' set to 200 with automatic increase by 100 and with 'MulTrees' option in effect. Bootstrap values were calculated based on 1000 replicates. A strict consensus tree was calculated from all of the most parsimonious trees obtained.

Bayesian analysis was performed for individual genes and the combined gene regions using the program MrBayes v3.1.2 (Ronquist \& Huelsenbeck 2003). The data set was partitioned into two gene regions. Analysis was performed using GTR+G+I model for COI, a GTR+G model for 16S. Parameters for the different partitions were unlinked to obtain separate parameter estimates for each gene and the rate prior was set to variable. Flat Drichlet priors were used in all analyses. Bayesian analyses were conducted by simultaneously running two Monte Carlo Markov chains, with one cold and three heated chains, for 5 million iterations. Trees were sampled every 200 iterations. Tracer v1.5 (Rambaut \& Drummond 2007) was used to monitor parameter stabilisation (via inspection of estimated sample size (ESS) and graphical plots of parameter sampling). The first $20 \%$ of trees sampled were consequently discarded as burn-in.

Maximum Likelihood analysis was conducted in RAxML (Randomized Axelerated Maximum Likelihood) version 8.20 (Stamatakis 2014) on the concatenated dataset under a GTR $+\mathrm{G}$ model. A single run was conducted with 1000 bootstrap inferences, followed by a thorough ML search. Each inference was initiated with a random starting tree, and employed the rapid hill-climbing algorithm (Stamatakis et al. 2007). FigTree v1.3.1 (Rambaut 2009) was used to view all tree topologies.

Haplotype phylogenetic relationships were assessed by a split-decomposition neighbour-net analysis on individual and combined dataset using SplitsTrees 4 (Huson \& Bryant 2006). 
Pairwise genetic distances ( $p$-distances) were calculated between groups using Mega 6 (Tamura et al. 2013) for COI and 16S. Groups were based on the well-supported lineages recovered within the phylogenetic analysis.

\section{Molecular diversity, molecular structure and historical demography}

Haplotype $(h)$ and nucleotide diversity $(\pi)$ for each gene region were assessed using DnaSP v. 5 (Librado \& Rozas 2009). Analysis of molecular variance (AMOVA), calculated in Arlequin version 3.5 (Excoffier \& Lischer 2010), was performed on the COI mtDNA locus to explore population structure within the genetic variation. Groupings tested within the AMOVA were based on the well-supported lineages recovered within the phylogenetic and neighbornetwork analyses. A population was defined as all individuals coming from a single geographic locality.

\section{Divergence analysis}

The node ages for the lineage-splitting events were estimated using the software BEAST v. 1.6.2 (Drummond \& Rambaut, 2007). Cytochrome Oxidase I (COI) data for those individuals successfully sequenced was used. As no fossil evidence with which to estimate time of origin for lineages is available for this group, we opted to use published mutation rates of 0.0075 and 0.012 (Brower 1994; Juan et al. 1995; Farrell 2001; Smith \& Farrell 2005; Wirta et al. 2008) mutational substitutions per site per million years (s/s/Myr), respectively, to cover the range of rates reported for COI mtDNA. A Bayesian relaxed molecular clock approach under the uncorrelated lognormal model and a Yule speciation was used for divergence time estimation. The ingroup was constrained to be monophyletic. The ML topology was specified as a starting tree for BEAST. Two independent MCMC analyses were run for 20 million generations with parameters sampled every 1000 generations. Default settings were kept for 
all other priors and operators. Tracer was used to monitor parameter stabilisation and assess the convergence between runs. LogCombiner v1.6.2 from the BEAST package was used to combine the tree and log output files from the two independent runs. The first $20 \%$ of trees sampled from each run was discarded as burn-in. The TreeAnnotator v1.6.2 application from the BEAST package was used to generate a maximum clade credibility tree and calculate the mean ages. Tree topologies were viewed in FigTree. The divergence analysis was run twice to validate consistency of the time estimates between runs.

\section{Morphology}

Where possible, male and female specimens from the different sampling localities were examined and male genitalia dissected and photographed. In addition, the holotype and several paratype specimens of $P$. capensis (Scholtz) were examined using Zeiss dissecting

microscopes. Images of set habitus specimens were taken with a Canon EOS 550D and $100 \mathrm{~mm}$ macro lens. Focus stacking was performed using the software Helicon Focus version 5.3. Male genitalia and components were photographed under a Leica M165 C microscope, using the Leica DMC 2900 digital camera. Morphological terminology follows Scholtz (1980).

\section{Results}

\section{Phylogenetic analysis}

The final combined molecular dataset consisted of 56 taxa and 1608 base pairs (bp): $\mathrm{COI}=$ $1152 \mathrm{bp}, 16 \mathrm{~S} \approx 456 \mathrm{bp} ; 252$ characters were parsimony informative, 1327 were constant and 280 were variable. Data characteristics and estimated model parameters for individual and combined datasets are shown in Table 2. 
Table 2. Data characteristics and estimated model parameters for COI, 16S and combined datasets.

\begin{tabular}{llll}
\hline & COI & $16 \mathrm{~S}$ & Combined \\
\hline Number of samples & 56 & 40 & 56 \\
Aligned positions & 1152 & 456 & 1608 \\
Parsimony informative sites & 227 & 25 & 252 \\
Tree length (MP) & 410 & 31 & 444 \\
Number of tree (MP) & 616 & 4 & 3360 \\
CI/RI & $0.680 / 0.959$ & $0.903 / 0.986$ & $0.691 / 0.960$ \\
Best fit model (AIC) & GTR+I+G & GTR+G & GTR+G \\
A frequency & 0.3246 & 0.3899 & 0.3467 \\
C frequency & 0.1583 & 0.1451 & 0.1574 \\
G frequency & 0.1413 & 0.0959 & 0.1260 \\
T frequency & 0.3758 & 0.3691 & 0.3698 \\
R(a) [AC] & 4.6039 & 2279.2626 & 5.0453 \\
R(b) [AG] & 18.3256 & 2980.1105 & 22.6645 \\
R(c) [AT] & 3.8626 & 1718.1791 & 3.1252 \\
R(d) [CG] & 1.0425 & 1.0000 & 1.6269 \\
R(e) [CT] & 31.2071 & 11551.1508 & 31.6934 \\
R(f) [GT] & 1.0000 & 1.0000 & 1.0000 \\
Gamma (G) & 0.4440 & 0.0150 & 0.1080 \\
Invariable sites (I) & 0.3890 & - & - \\
\hline CI = consistency index, RI = retention & index, MP & Maximum Parsimony, AIC = Akaike Information \\
Criterion. & & & \\
& & & \\
\hline
\end{tabular}

The heuristic search from the parsimony analysis produced 3360 most parsimonious trees, with tree length $=444$, consistency index $(C I)=0.691$ and retention index $(\mathrm{RI})=0.960$. The strict consensus tree, with nodal support, is presented in Fig A1 in the Appendix. Trees obtained from the BI and ML analyses yield very similar topologies, hence only the Bayesian phylogram is presented with Bayesian posterior probability (PP) and ML bootstrap support (BS) for nodes (Fig 3). The resulting neighbour-net splits tree (Fig 2) for the combined dataset had a recomputed fit $=93.01$, and LS fit $=99.48$. Individual gene trees and splitsgraphs show similar phylogenetic groupings as for the combined dataset and are thus not presented. 
Figure 2: Neighbour-net graph for the mtDNA COI dataset with bootstrap support, based on uncorrected $p$ distances.

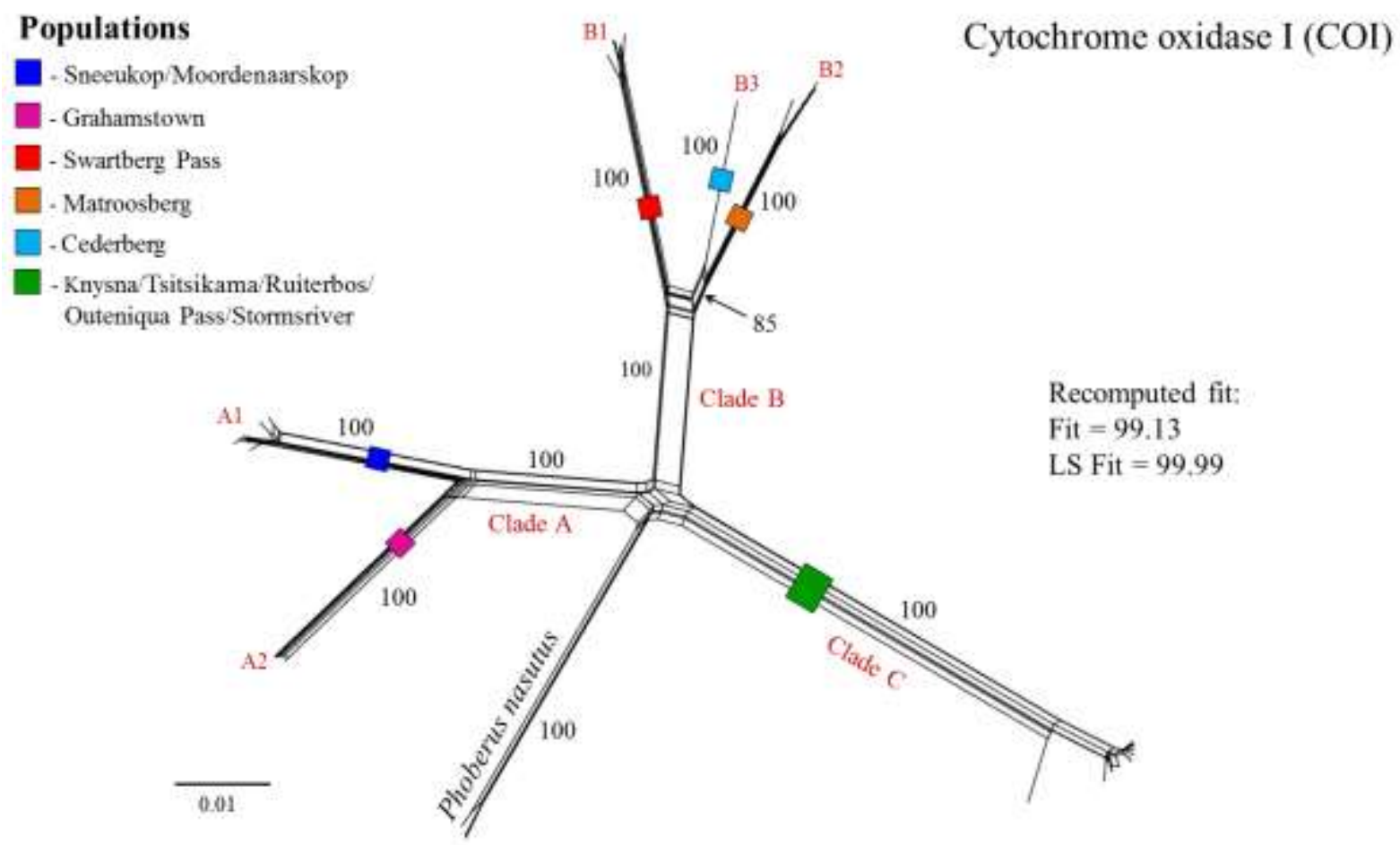

Three distinct evolutionary lineages (nodes A, B and C), each with strong nodal support (PP $=1.0, \mathrm{BS}=100 ;$ Fig 2 and 3), were recovered across all methods of analysis. Clade A is divided into two well-supported $(\mathrm{PP}=1.0, \mathrm{BS}=100$; Fig 2 and 3$)$, geographically separated populations, Sneeukop/Moordenaarskop (node A1) and Grahamstown (node A2). Clade B split into three well-supported $(\mathrm{PP}=1.0, \mathrm{BS}=100)$ geographically discrete populations, representing the Swartberg Pass (node B1), Matroosberg (node B2) and Cederberg (node B3) sampling localities. Clade $\mathrm{C}(\mathrm{PP}=1.0, \mathrm{BS}=100$; Fig 2 and 3$)$ comprises taxa from several localities: Knysna, Tsitsikama, the Outeniqua Pass, Ruiterbos and Stormsrivier. Phylogenetic relationships in this clade are not well-resolved and taxa are interspersed on the tree, despite obvious geographical separation among the populations. 
Figure 3: Bayesian topology from the MrBayes analysis for the combined dataset. Numbers next to each node are (ML) bootstrap support and the (BI) posterior probabilities. Images depict the male genitalia type for the respective lineages.

\section{Populations/Localities}

- Sneeukop/Moordenaarskop

D- Grahamstown

- Swartberg Pass

- Matroosberg

$\square$ - Cederberg

- Knysna/Tsitsikama/Ruiterbos/ Outeniqua Pass/Stormsriver

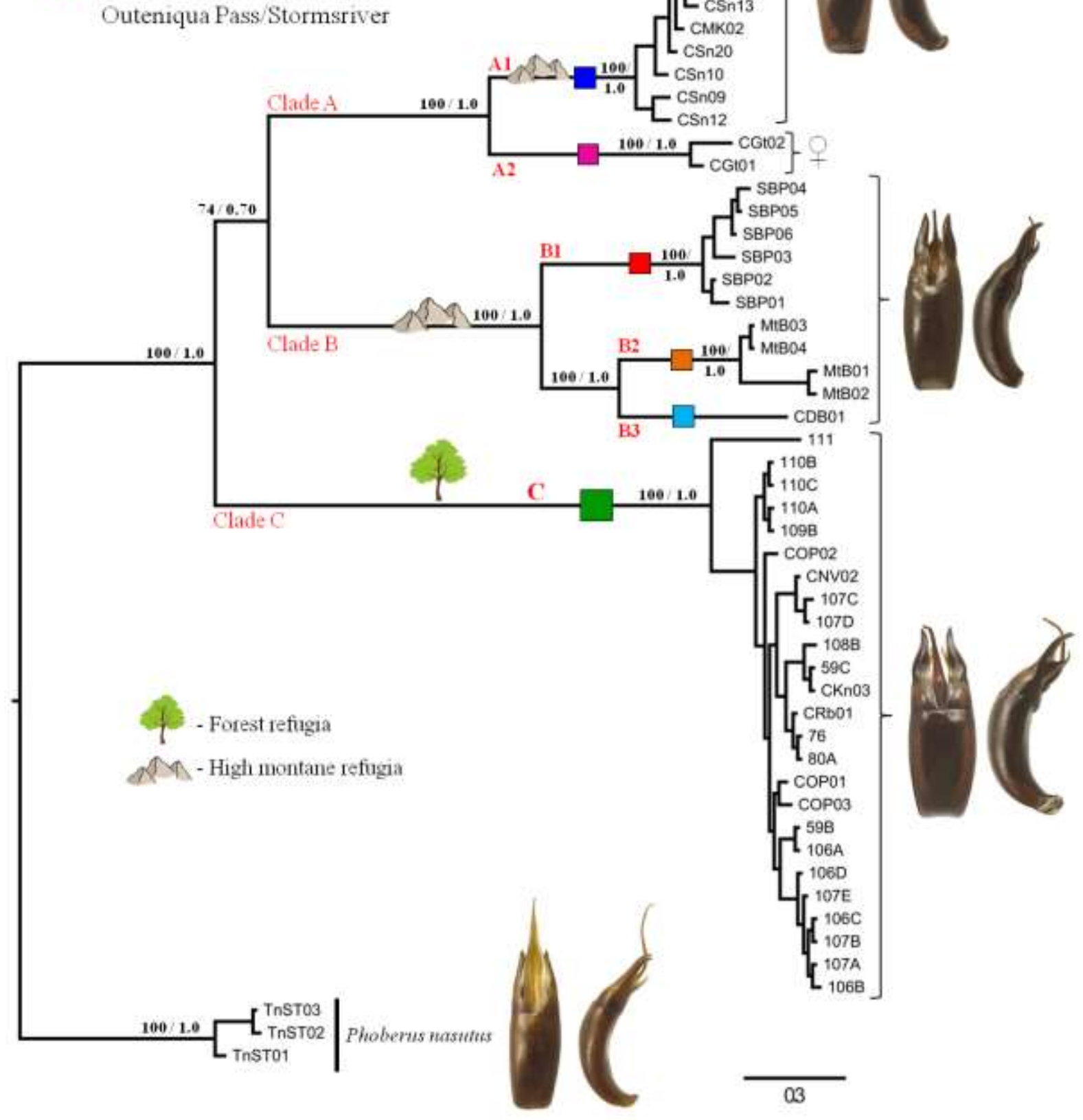


For COI, pairwise genetic distances between defined groups (Table 3) range from 5.4\% to $11.9 \%$, and for $16 \mathrm{~S}$ between $0.4 \%$ and $2.6 \%$. The percentage pairwise genetic distance, for COI within clades (A,B,C) was low overall, with $3.93 \%$ for clade A, $1.4 \%$ for clade B and $0.5 \%$ for clade $\mathrm{C}$, and for $16 \mathrm{~S}$ it was $0.5 \%$ for clade $\mathrm{A}, 0.1 \%$ for clade B and $0.1 \%$ for clade C.

Table 3. Percentage pairwise genetic distances between and within clades for COI (below the diagonal) and 16S (above the diagonal).

\begin{tabular}{|c|c|c|c|c|c|c|}
\hline & A1 & A2 & B1 & B2 & B3 & $\mathrm{C}$ \\
\hline A1 & & $0.7 \%$ & \multirow{2}{*}{\multicolumn{3}{|c|}{$1.9 \%$}} & \multirow{2}{*}{$2.3 \%$} \\
\hline A 2 & $5.4 \%$ & & & & & \\
\hline B1 & \multirow{3}{*}{\multicolumn{2}{|c|}{$10.4 \%$}} & & $0.7 \%$ & $0.4 \%$ & \multirow{3}{*}{$2.6 \%$} \\
\hline B2 & & & $5.7 \%$ & & $0.2 \%$ & \\
\hline B3 & & & $6.0 \%$ & $4.9 \%$ & & \\
\hline $\mathrm{C}$ & \multicolumn{2}{|c|}{$11.7 \%$} & \multicolumn{3}{|c|}{$11.9 \%$} & \\
\hline
\end{tabular}

\section{Genetic structure and population genetics}

Among the 53 individuals of $P$. capensis sequenced for COI, 32 different haplotypes were identified while only 11 haplotypes were identified from the 38 individuals sequenced for 16S. Haplotype diversity for COI was high $(0.962 \pm 0.014)$ and somewhat lower but more variable for $16 \mathrm{~S}(0.83 \pm 0.031)$. Nucleotide diversity for COI was $0.069 \pm 0.0035$ with the average nucleotide differences being 79.827 , while $16 \mathrm{~S}$ had a nucleotide diversity of 0.01834 \pm 0.00142 and an average nucleotide difference of 8.215. Statistics of general nucleotide diversity are summarised in Table 4 . There were no shared haplotypes among the three clades $(\mathrm{A}, \mathrm{B}, \mathrm{C})$ and between populations within clades, indicating no gene flow between these populations or possible sampling artefacts, e.g. small sample sizes. The fixation value $\left(\mathrm{F}_{\mathrm{st}}\right)$ of $0.8570(p<0.001)$ from the AMOVA analysis indicated strong genetic structure between the 
three clades. Differences among the three groups accounted for $85.70 \%$ of the variance, while $14.30 \%$ could be attributed to variation among populations within groups.

Table 4. Summary of $\mathrm{F}_{\mathrm{st}}$ statistics calculated by AMOVA (Excoffier \& Lischer 2010) for Phoberus capensis.

\begin{tabular}{lccc}
\hline Source of Variation & $\mathrm{F}_{\mathrm{st}}$ & $\%$ & $P$ \\
\hline Among-groups variation & & 85.7 & $<0.001$ \\
Within-groups variation & & 14.3 & $<0.001$ \\
Fixation index & 0.8570 & & $<0.001$ \\
\end{tabular}

\section{Divergence times}

The divergence time analyses indicate that the $P$. capensis complex is 3.77 or $6.03 \mathrm{Myr}$ old, for 0.012 and $0.0075 \mathrm{~s} / \mathrm{s} / \mathrm{Myr}$, respectively (Table 5). Phoberus capensis diverged from its closest relative, $P$. nasutus (outgroup), at 4.3 or 6.85 mya. Divergence within clade B occurred 2.06 or 3.76 mya, while divergence within clade A occurred 1.95 or 3.06 Mya. Clade C diverged around 1.33 or 2.13 mya.

Table 5. Time to most recent common ancestor (in millions of years) for the lineages identified in the phylogenetic tree (Fig 3).

\begin{tabular}{lll}
\hline Clade & \multicolumn{2}{l}{ Substitution rate } \\
\cline { 2 - 3 } & 0.012 & 0.0075 \\
\hline Clade A & $1.95(0.98,3.36)$ & $3.06(1.47,5.29)$ \\
Sneeukop/Moordenaarskop (A1) & $0.85(0.31,1.78)$ & $1.34(0.5,2.79)$ \\
Clade A+Clade B & $3.3(1.95,5.24)$ & $5.26(3.05,8.17)$ \\
Clade B & $2.06(1.09 ; 3.41)$ & $3.27(1.68,5.44)$ \\
Matroosberg (B2) + Cederberg (B3) & $1.34(0.56 ; 2.36)$ & $2.12(0.91,3.80)$ \\
Matroosberg (B2) & $0.53(0.15 ; 1.16)$ & $0.84(0.23,1.86)$ \\
Swartberg Pass (B1) & $0.58(0.17 ; 1.33)$ & $0.93(0.25,2.18)$ \\
Clade C & $1.33(0.54,2.70)$ & $2.13(0.81,4.24)$ \\
Ingroup & $3.77(2.19,5.96)$ & $6.03(3.47,9.43)$ \\
Root & $4.3(2.46,6.94)$ & $6.85(3.85,11.01)$ \\
\hline Upper and & & \\
\hline
\end{tabular}

Upper and lower 95\% confidence limits are shown in parentheses. 


\section{Morphology}

Pronotal and elytral features in P. capensis vary greatly with size of the individual. In smaller specimens, many features tend to be more irregular or obscured (for example intercostal punctures and fovae) and/or pronounced (like tubercles and ridges), thus making it difficult to identify characters that can be used to identify clades/groups within P. capensis. Despite the lack of diagnostic pronotal and elytral characters, fairly consistent differences exist between specimens of clade B and clades A and C. Specimens from the Cederberg, Matroosberg and Swartberg Pass (Clade B) are generally smaller (4-7mm) and have the discal area of the pronotum more evenly rounded, with a shallow median depression and tubercles that are not distinctly raised. Members of clade A and C are larger $(5-10 \mathrm{~mm})$ and the discal area of the pronotum is raised, with a deep median depression and distinct tubercles. Examination of the male genitalia shows three major types corresponding to the recovered clades A1, B and C. However, variation in the male genitalia within each clade, the small number of male specimens available for study and the lack of male specimens from Grahamstown (A2), make it difficult to distinguish between all clades on the basis of male genitalia alone.

\section{Discussion}

Phylogeny and divergence time estimates

Despite the small sample sizes from some localities, the results of this study indicate there are at least three well-supported evolutionary lineages within $P$. capensis with high (10-12\%) sequence divergence between them at the COI locus, which is similar to that found for other flightless scarabaeoids (Sole \& Scholtz 2013; Switala et al. 2014). The high sequence divergence between the three clades justifies recognising them as distinct species using previously-cited threshold values recorded between closely related insect species (Herbert et al., 2003; Price et al. 2007; Astrin et al. 2012; for limitations of genetic distance as a criterion 
in delineating species see Ferguson (2002) and Brower (2006)). All three clades (A, B and C) are geographically discrete with apparently no dispersal between them (Fig 1).

The results show that clades A and B may comprise divergent and geographically distinct populations which can be interpreted as phylogenetically independent lineages. However, these populations are morphologically indiscernible and due to the small number of specimens obtained from the different localities, we refrain from drawing any conclusions regarding the (taxonomic) status of these populations and will not discuss them further here.

Molecular dating hypothesised the diversification of the $P$. capensis group during the Pliocene-Pleistocene. This time period was characterised by habitat and vegetation shifts associated with climatic change in the CFR (Cowling et al. 2009; Swart et al. 2009; Tolley et al. 2006), and the contraction of forested areas and with the establishment of 'fynbos' as the spatially dominant vegetation ( 3 to 5 mya; Linder 2003; Galley \& Linder 2006). Based on results of this study, it is suggested that $P$. capensis experienced climatically-driven allopatric speciation with sheltered Afrotemperate forest and high mountain peaks serving as important refugia during climatic ameliorations (Stuckenberg 1962; Endrödy-Younga 1978; Picker \& Samways 1996; Voje et al. 2009; Daniels et al. 2013). Phoberus capensis thus represents a speciation process in which flight-restricted populations evolved in close allopatry, possibly as recently as the Pleistocene.

\section{Taxonomic consideration}

These results indicate that the samples represented at least three distinct species according with the phylogenetic species concept (Nixon \& Wheeler 1990; Wheeler \& Platnick 2000). The Hottentots-Holland clade (clade A) from the Sneeukop/Moordenaarskop localities has 
morphology identical to the type material of Phoberus capensis (Scholtz 1979). The type locality for P. capensis is the nearby Jonkershoek Mountain (Scholtz 1980). In stark contrast, situated about $600 \mathrm{~km}$ east of the Hottentots-Holland Mountains is the Grahamstown sister population (A2) and the most easterly distribution for P. capensis. This population may represent a distinct lineage, but with only two female specimens at our disposal its status remains uncertain and warrants further investigation.

The Swartberg assemblage (clade B), comprises specimens collected from three different mountain ranges, Cederberg, Matroosberg and Swartberg. They are morphologically uniform and can be distinguished from the other two lineages by differences on the pronotum and male genitalia. The different mountain populations are genetically divergent and may represent novel lineages but this requires further investigation. Extensive sampling is needed in the region to delineate distribution boundaries.

The Southern Cape clade (clade C) has a large and fragmented distribution mostly in the Afrotemperate forests along the southern coast (Knysna and Tsitsikama) and in the high-lying forest fragments in the CFM (Outeniqua, Tsitsikama and Langeberg Mountain ranges). The unresolved phylogenetic relationships within the clade, their low divergence, and close association with Afrotemperate forests, suggest that these localities/populations may have been connected in the recent past when forests were widely continuous in southern and eastern Africa (Partridge et al. 1999).

On the basis of the differences discussed above we describe two novel species. Phoberus capensis (Scholtz) has had an inconstant taxonomic history. In his original description Scholtz (1979), at the time, treated P. capensis as a member of the genus Trox Fabricius, and 
placed it in the subgenus Phoberus MacLeay in his revision of the Afrotropical species (Scholtz 1980), and in his revision of the Trogidae (Scholtz 1986), T. capensis was transferred to Trox s.str. However, recent molecular evidence suggests that all Afrotropical species of Trox form a monophyletic group, falling within Phoberus (Strümpher et al. 2014). Strümpher et al. (2014) were explicit that Phoberus merits higher taxonomic status and in their paper Trox capensis has already been informally placed in Phoberus as a genus. Strümpher et al. (2015) subsequently restored Phoberus to genus rank to include all of the Afrotropical (including Madagascan endemic) species. From a nomenclatural perspective we thus consider T. capensis and the novel species described here as members of the genus Phoberus MacLeay. Descriptions of the new species are limited to characters with past diagnostic value. No differences were observed in the external morphology of males and females. Members of the species complex are morphologically similar to P. nasutus (Harold) and can best be distinguished on the basis of the male genitalia (Scholtz 1980).

\section{Systematics}

Type specimens

Scholtz (1979) in his original generated a large type series (225 specimens) which he deposited in collections around the world. For logistical reasons not all type material was reexamine. Nonetheless, the bulk of the type series (160 specimens), including the holotype, were retained at the Ditsong Museum of Natural History (TMSA) and the Department of Zoology \& Entomology, University of Pretoria (UPSA). We deemed the number of primary types available for examination sufficient for this study. All paratypes designated by Scholtz (1979) and the collections housing type material are listed within this paper in the type material section under the description of the each taxon. Type material that could not be examined is marked by an asterisk (*) next to the repository acronym. All label data were 
cited verbatim and information on type material examined was copied using "/" between lines, and "//" between labels.

Institutions to which new specimens or type material belongs or in which they have been deposited are abbreviated as follows:

AMNH: American Museum of Natural History, New York, NY, USA

BMNH: The Natural History Museum, London, UK

HMUG: Hunterian Museum, University of Glasgow, Glasgow, UK

HNHM: Hungarian Natural History Museum, Budapest, Hungary

ISNB: Institut Royal des Sciences Naturelles de Belgique, Brussels, Belgium

MNHN: Muséum National d'Histoire Naturelle, Paris, France

MZLU: Museum of Zoology, Lund University, Lund, Sweden

NMK: National Museums of Kenya, Nairobi, Kenya

NCSA: National Collection of Insects, Roodeplaat, Pretoria, South Africa

NHRS: Naturhistoriska Riksmuseet, Stockholm, Sweden

RMCA: The Royal Museum for Central Africa, Tervuren, Brussels, Belgium

SAM: Iziko South African Museum, Cape Town, South Africa

SMTD: Staatliches Museum für Tierkunde, Dresden, Germany

SMW: State Museum, Windhoek, Namibia

TMSA: Ditsong Museum of Natural History, Pretoria, South Africa

UPSA: Department of Zoology \& Entomology, University of Pretoria, South Africa

ZMUC: Zoological Museum, University of Copenhagen, Copenhagen, Denmark

ZSBS: Zoologische Sammlung des Bayerischen Staates, Munich, Germany

Genus: Phoberus MacLeay, 1819 
Phoberus MacLeay, 1819: 137-138; Strümpher et al. 2014: 557-558; Strümpher et al. 2015:

15.

Phoberus capensis (Scholtz) (Plate A: 1a, b; Figs 2, 3: Clade A)

Trox capensis Scholtz 1979:174

Trox (Phoberus) capensis Scholtz, 1980:71

Trox (Trox) capensis Scholtz, 1986: 361

Phoberus capensis Strümpher et al., 2014: Table S1 ff.; Strümpher et al., 2015: 27.

\section{Diagnosis}

Phoberus capensis is morphologically similar to $P$ disjunctus sp. n., but can be distinguished from the latter by the raised discal area of the pronotum and deep median depression and distinct tubercles. Phoberus disjunctus sp. n. has the discal area of the pronotum more evenly rounded, with a shallow median depression and tubercle not distinctly raised. Male genitalia of both species are distinct (Plate A: 1b).

\section{Redescription}

Size: 7-8 mm, width: $4-5 \mathrm{~mm}(n=20)$.

Head: Clypeus triangular; frons with two oval setose ridges; antennal scape setose, slightly longer than wide, pedicel attached to apex of scape.

Pronotum: Attenuated anteriorly, sides broadly flattened, surface pitted; lateral margins with fringes of short setae; discal area raised, median depression deep divided into two halves by low transverse ridge, anterior half of median depression broad, posterior half narrow; discal ridges high, interrupted approximately in middle; median basal tubercles fused to discal 
Plate A: 1(a) Adult habitus of Phoberus capensis (Scholtz); 1(b) Aedeagus of Phoberus capensis (Scholtz): dorsal and lateral view. 2(a) Adult habitus of Phoberus disjunctus sp. n.; 2(b) Aedeagus of Phoberus disjunctus sp. n.: dorsal and lateral view. 3(a) Adult habitus of Phoberus herminae sp. n.; 3(b) Aedeagus of Phoberus herminae sp. n.: dorsal and lateral view.
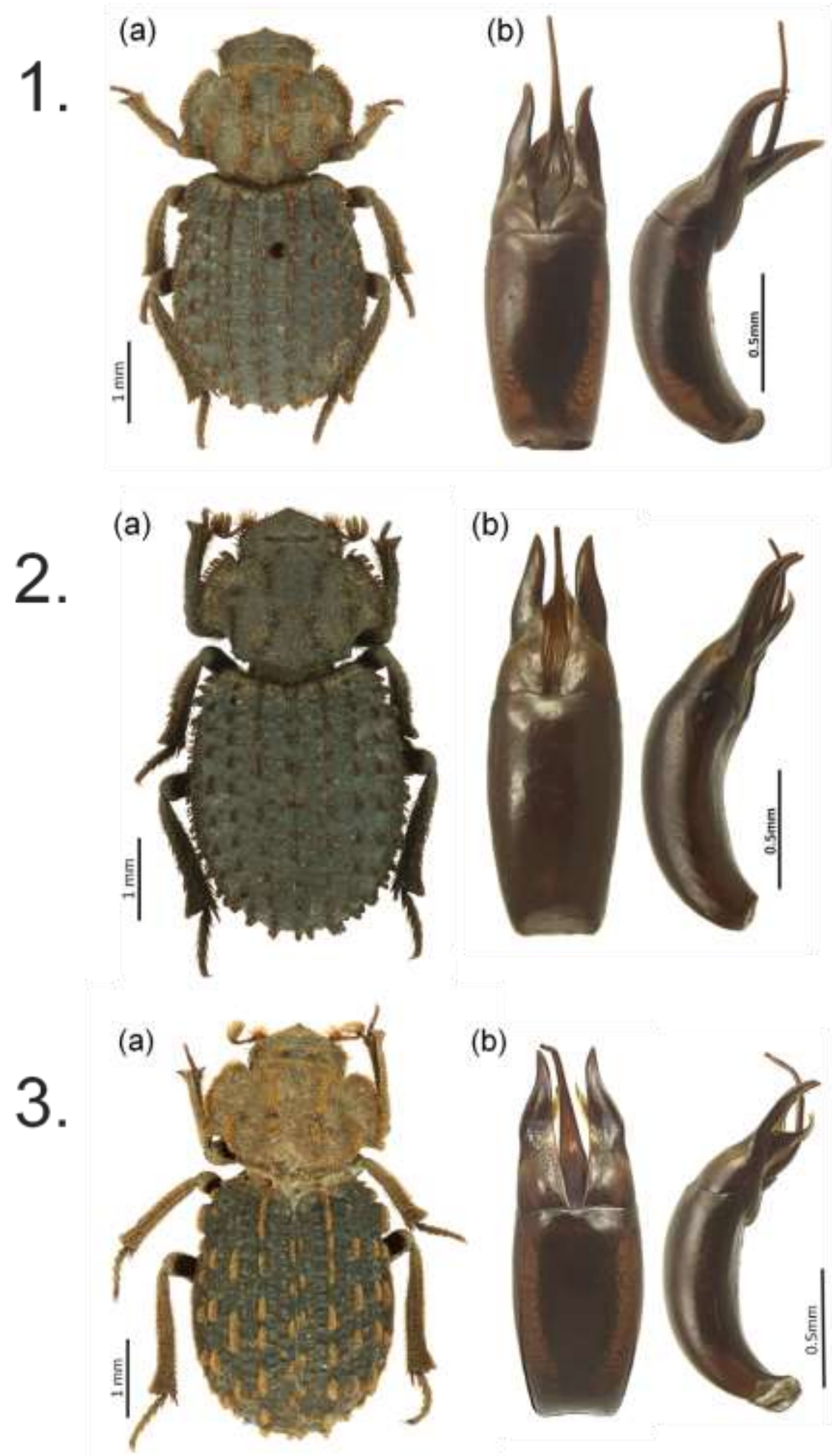

(b)

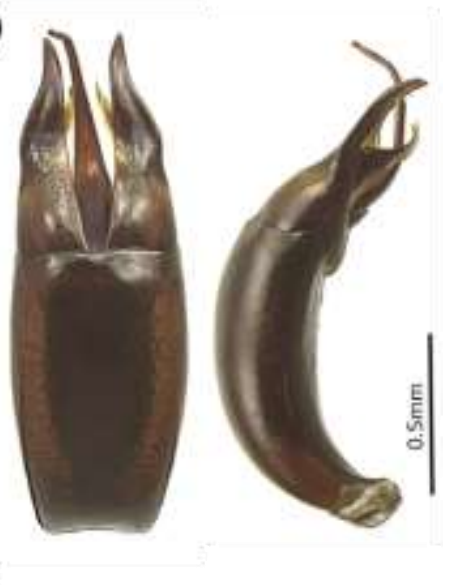


ridges; another ridge is present laterad of, and parallel to, the median ridges, ridges and tubercle setose.

Elytra: Scutellum small and oval, humeral calli absent; sides flattened; lateral margins with fringes of short setae; even numbered costae distinct, tubercles with tufts of setae, tubercles raised, single or partially fused to form distinct ridges; odd numbered costae indistinct; intercostal punctures irregular large and shallow; elytral profile convex, attaining maximum height behind middle.

Male genitalia: parameres symmetrical, attenuated towards the apex, parameres curving distinctly downwards, pars basalis thick, not distinctly c-shaped and slightly longer than parameres, ratio of length of parameres to length of pars basalis about 1:1. Median lobe exposed in dorsal view, flattened basally and attenuated sharply into long, narrow pointed projection (flagellum) extending beyond parameres; pair of blade-like projections ventrally between parameres (Plate A: 1b).

Distribution: Phoberus capensis is restricted to the Hottentots-Holland Mountain range in the greater Cape Fold Mountain Range and confined to the high mountain peaks (Fig 1).

Type material: Holotype, ỗ: Jonkershoek Mnt. / Forest Reserve / SE 3319 Cc / 20.XII.1978 /

C.H. Scholtz (TMSA); Paratypes: Ditto (10 UPSA*; 3 BMNH*; 3 MNHMS*; 3 NHRS*; 3 ISNB*; 3 RMCA*; 3 ZSBS*; 3 HNHM*; 3 NCSA*; 3 SMW*; 3 SAM*); S. Afr., S.W. Cape / Nuweberg, Sneeukop / 34.03S - 18.59E // 16.XI.1973, E-Y: 265 / ground traps, 130 days / leg. Endrödy-Younga (30 TMSA; 1 UPSA; 1 BMNH*; 1; MNHN*; 1 NHRS*; 1 ISNB*; 1 RMCA*; 1 ZSBS*; 1 HNHM*; 1 NCSA*; $1 \mathrm{SMW}^{*}$; 1 SAM*); S. Afr., W. Cape / Nuweberg Camp / 34.03S 19.04E // 14.XI.1973, E-Y: 244 / groundtrap: fish / leg. Endrödy-Younga (13 TMSA; 1 UPSA; 1BMNH*; 1 ISNB*; 1 RMCA*; 1 ZSBS*); S. Afr.: W. Cape / Hawequas / 333'ㅅ 1908'E // 5.XI.1973, E-T: 202 / sifted litter / leg. / Endrödy-Younga (2 TMSA); Stellenbosch / 20.7.1965 / H. Geertsema (1 UPSA). 
Type material examined bears the new type label: HOLOTYPE [or PARATYPE] / Phoberus capensis (Scholtz) / Strümpher et al. 2015 (printed on white rectangle with red border).

Additional material examined: RSA: Western Cape Prov. / Caledon, Sneeukop / HottentotsHolland Mnts. / S34.05000 E18.98333 / 16.XI.1973, E-Y: 265 / Soil trap, Coll: EY-STR (20 TMSA).

Phoberus disjunctus Strümpher sp. n. (Plate A: 2a, b; Figs 2, 3 Clade B)

\section{Diagnosis}

Phoberus disjunctus is similar to $P$. capensis but can be distinguished from the latter by an evenly rounded pronotal disc and shallow median depression; $P$. capensis has a high pronotal disc with a deep median depression. Male genitalia of both species are distinctive (Fig 3; Plate A).

\section{Description}

Size: 5-6 mm, width: 3-4 mm $(n=25)$.

Pronotum: discal area of pronotum evenly rounded, with shallow median depression, tubercle not distinctly raised.

Male genitalia: parameres symmetrical, attenuated towards the apex, in lateral profile straight and curved apically; pars basalis longer than parameres, the ratio of length of parameres to length of pars basalis about 1:1.5, pars basalis variable in shape and thickness; median lobe exposed in dorsal view, flattened basally and attenuated sharply into short narrow pointed projection (flagellum) only slightly longer than parameres; genitalia in ventral view with a pair of blade-like projections between parameres (Plate A: 2b). 
Distribution: This species is distributed (disjunctly) along the Swartberg, Matroosberg and the Cederberg Mountains in the greater Cape Fold Mountain Range and confined to the high mountain peaks (Fig 1).

Type material: Holotype $\widehat{\jmath}:$ S. Afr.: Cape, Cederberg / Jeep track, 1380 m / 32.24S - 19.10E // 01.IX.1981, E-Y: 1878 / ground traps, 63 days / leg. Endrödy-Younga // ground traps with meat bait // Trox capensis Scholtz / det. C.H. Scholtz (white rectangle printed) (TMSA); Paratypes: S. Afr.: Cape, Cederberg / Jeep track, 1380 m / 32.24S - 19.10E // 01.IX.1981, EY: 1878 / ground traps, 63 days / leg. Endrödy-Younga // ground traps with meat bait // Trox capensis Scholtz / det. C.H. Scholtz (white rectangle printed) (2 TMSA); S. Afr: Swartberge / Blesberg - E[ast], 2000 m / 23[33].25S - 22.41E // 06.XI.1978, E-Y: 1508 / ground traps, 40 days / leg. Endrödy-Younga // ground traps with faeces bait (9 TMSA); S. Afr: Swartberge / Blesberg - E[ast], 2000 m / 23[33].25S - 22.41E // 05.XI.1978, E-Y: 1505 / ground traps, 41 days / leg. Endrödy-Younga // ground traps with faeces bait (10 TMSA); S. Afr: Swartberge / Blesberg - W[est], 1820 m / 33.25S - 22.40E // 06.XI.1978, E-Y: 1512 / ground traps, 41 days / leg. Endrödy-Younga // ground traps with meat bait (1 TMSA); S. Afr: Swartberge / Blesberg - W[est], 1820 m / 33.25S - 22.40E // 06.XI.1978, E-Y: 1513 / on flowers / leg. Endrödy-Younga (1 TMSA); S. Afr: Swartberge / Blesberg - W[est], 1850 m / 33.24S 22.40E // 07.XI.1978, E-Y: 1514 / ground traps, 40 days / leg. Endrödy-Younga // ground traps with meat bait (4 TMSA); RSA: Western Cape Province / Swartberg Range, Blesberg / 33.25S 22.41E, 1820 m // 16.XII.1987, E-Y: 1532B / leg. Endrödy-Younga, (1 NCSA; 4 TMSA; 2 UPSA); RSA: Western Cape Prov. / Swartberg Pass, nr. Oudtshoorn / 13.III.1979, ground traps (meat) / Coll: Breytenbach (3 UPSA).

Type material examined bears the new type label: HOLOTYPE [or PARATYPE] / Phoberus disjunctus sp.n. / Strümpher et al. 2015 (printed on white rectangle with red border). 
Etymology: From the Latin disjunctus, meaning separated or disconnected, in reference to the disjunct montane distribution of this species.

Phoberus herminae Strümpher sp. n. (Plate A: 3a, b; Figs 2, 3 Clade C)

\section{Diagnosis}

Phoberus herminae has very similar external morphology to P. capensis, and the only reliable means of identification involves the male genitalia. Constant differences exist in the shape of the parameres and the median lobe (Fig 3; Plate A).

\section{Description}

Size: 7-10 mm, width: 4-6 mm $(n=28)$.

External morphology as for P. capensis.

Male genitalia: parameres symmetrical, attenuated towards the apex, parameres curved, pars basalis thick, c-shaped and longer than parameres, ratio of length of parameres to length of pars basalis about 1:1.5. Median lobe exposed in dorsal view, flattened basally and attenuated broadly into narrow pointed projection (flagellum) extending beyond parameres, often with knob-like structure on apex; genitalia with a single pair of ventral blade-like projections between parameres (Plate A: 3b).

Distribution: This species is distributed (disjunctly) along coastal edge and the Tsitsikama, Outeniqua and Langeberg Mountain Ranges of the south Western Cape Province (Fig 1). Type material: Holotype ỡ: S. Afr., Cape Prov. / Knysna forest / 22km N Knysna // 0812.III.1992 / leg. J. Klimaszweski (TMSA). Paratypes: S. Afr., Cape Prov. / Knysna Forest / 22km N Knysna // 08-12.III.1992 / leg. J. Klimaszweski (TMSA 2; UPSA 2); Baviaanskloof 
Mnts. / Studtis, SE 3323 Db / 1627m, 09.VIII.1978 / E. Breytenbach (3 UPSA; 1 BMNH*; 1 MNHN*; 1 NHRS*); S. Afr., S. Cape / Harkerville Forest / 34.04.S - 23.10E // 13.12.1976 / E-Y: 1311 / ground traps, 4 days / leg. Endrödy-Younga // ground traps with / faeces bait (6 TMSA; 2 UPSA; 1 MNHN*); Bloukrans Forest / Knysna, SE 3423 Ab / Jan.1978 / C.H. Scholtz (1 UPSA); Goudveld Forest / Knysna, SE 3322 Dd / Jan. 1978 / C.H. Scholtz (1 UPSA; 1 SMTD*); Kafferkop Forest / Knysna, SE 3423 Aa / Jan.1978 / C.H. Scholtz (1 UPSA); Tsitsikama Forest / SE 3323 Dc, Jan.1978 / C.H. Scholtz (2 UPSA); S. Afr., S. Cape / Keurboomstrand / 34.00S - 23.27.E // 18.12.1976, E-Y: 1301 / ground traps 8 days / leg. Endrödy-Younga (4 TMSA; 1 UPSA); Bergplaas Forest / Knysna, SE 3322 Dc / Jan.1979 / J.H. Botha (2 UPSA; 2 AMNH*; 2 ZMUC*; $^{*}$ HMUG*; $^{*}$ ISNB*; $^{*}$ NMK*; 1 RMCA*); S. Afr.: S. CapeMt. / Grootberg, W., 1450 m / 33.55S 20.51E // 2.XI.1978, E-Y: 1501 / groundtraps, 35 days / leg. Endrödy-Younga // ground traps with faeces bait (49 TMSA). Ysternek Forest / Knysna, SE 3323 Cc / Jan.1978 / C.H Scholtz (1 UPSA; 1 RMCA*; 1 ZSBS*); Diepwalle Forest / Knysna, 3323 Cc / Jan.1978 / C.H. Scholtz (1 MZLU*).

All type material examined bears the new type label: HOLOTYPE [or PARATYPE] / Phoberus herminae sp. n. / Strümpher et al. 2015 (printed on white rectangle with red border).

Additional material examined: RSA: Western Cape Province / Outeniqua Pass, 25.XII.2007 / S33.90000 ${ }^{\circ}$ E22.40107 ${ }^{\circ}, 668 \mathrm{~m} /$ Baited pitfall trap, C Deschodt (5 UPSA); S. Afr: Cape Prov. / Lily Vlei Nat. Res. / 33.56S 23.02E // Gouna State Forest, IV.1983, , J. Koen (12 TMSA; 4 UPSA); S. Afr.: Cape Prov. / Diepwalle St. Forest / 33.56S 23.09E // January1984 / dry forest litter / leg. J. Koen (2 UPSA); Diepwalle St. Forest / 33.56S 23.09E // February 1984 / dry forest litter / leg. J. Koen (1 TMSA); Diepwalle St. Forest / 33.56S 23.09E // 02. 
1984 / wet forest / leg. J. Koen (1 TMSA); S. Afr.: Cape Prov. / Groenkop / 33.57S 22.33E // January 1985 / pitfall trap / leg. J. Koen (2 TMSA); S. Afr.: Cape Prov. / Groenkop / 33.57S

22.33E // February 1985 / pitfall trap / leg. J. Koen (2 TMSA); S. Afr.: Cape Prov. /

Groenkop / 33.57S 22.33E // 7. 1985 / pitfall trap / leg. J. Koen (3 TMSA); S. Afr.: Cape

Prov. / Groenkop / 33.57S 22.33E // 10. 1985 / pitfall trap / leg. J. Koen (3 TMSA); S. Afr.:

SE Cape Mts / Baviaanskloofberg / 33.36S - 24.23E // 15.XI.1982, 1035 m. / groundtraps, 30 days / leg. W. Breytenbach // ground traps with meat bait (8 TMSA).

Etymology: It is with great pleasure that I name this species after my wife Hermien Viljoen for her support of my entomological pursuits.

\section{Acknowledgements}

We are grateful to members of the Scarab Research Group, at the University of Pretoria, for field assistance. We thank Ruth Müller of the Ditsong Museum of Natural History, Pretoria, for lending us their valuable specimens for this study, and two anonymous reviewers for their helpful comments. This project was supported by funding to Clarke H. Scholtz from the National Research Foundation of South Africa (NRF). We acknowledge and thank Cape Nature (Western Cape Province) for granting permits for field collections.

\section{References}

Akaike, H. (1974) A new look at the statistical model identifications. IEEE Transactions on Automatic Control 19: 716-723.

Astrin, J.J., Stüben, P.E., Misof, B., Wägele, J.W., Gimnich, F., Raupach, M.J. \& Ahrens, D. (2012) Exploring diversity in cryptorhynchine weevils (Coleoptera) using distance-, character- and tree-based species delineation. Molecular Phylogenetics and Evolution 63: 1-14. 
Brower, A.V.Z. (1994) Rapid morphological radiation and convergence among races of the butterfly Heliconius erato inferred from patterns of mitochondrial DNA evolution. Proceedings of the National Academy of Sciences USA 91: 6491-6495.

Brower, A.V.Z. (2006) Problems with DNA barcodes for species delimitation: 'ten species' of Astraptes fulgerator reassessed (Lepidoptera: Hesperiidae), Systematics and Biodiversity 4: $127-132$.

Cowling, R.M., Proches, S. \& Partridge, T.C. (2009) Explaining the uniqueness of the Cape flora: incorporating geomorphic evolution as a factor for explaining its diversification. Molecular Phylogenetics and Evolution 51: 64-74.

Daniels, S.R., McDonald, D.E. \& Picker, M.D. (2013) Evolutionary insight into the Peripatopsis balfouri sesu lato species complex (Onychophora: Peripatopsidae) reveals novel lineages and zoogeopraphic patterning. Zoologica Scripta 42(6): 656-674.

Deschodt, C.M., Davis, A.L.V. \& Scholtz, C.H. (2011) New dung beetle (Coleoptera: Scarabaeidae: Scarabaeinae) taxa from arid south-western Africa. Insect Systematics and Evolution 4: 277294.

Deschodt, C.M., Kryger, U. \& Scholtz, C.H. (2007) New taxa of relictual Canthonini dung beetles (Scarabaeidae: Scarabaeinae) utilizing rock hyrax middens as refuges in South-western Africa. Insect Systematics and Evolution 38: 361-376.

Deschodt, C.M. \& Scholtz, C.H. (2008) Systematics of South African forest-endemic dung beetles: new genera and species of small Canthonini (Scarabaeidae: Scarabaeinae). African Entomology 16(1): 91-106.

Dupanloup, I., Schneider, S. \& Excoffier, L. (2002) A simulated annealing approach to define the genetic structure of populations. Molecular Ecology 11: 2571-2581.

Dupont, L.M., Linder, H.P., Rommerskirchen, F. \& Schefuß, E. (2011) Climate-driven rampant speciation of the Cape flora. Journal of Biogeography 38(6): 1059-1068.

Drummond, A.J., Ho, S.Y.W., Phillips, M.J. \& Rambaut, A. (2006) Relaxed phylogenetics and dating with confidence. PLoS Biol. 4(5): 699-710. 
Drummond, A.J. \& Rambaut, A. (2007) BEAST: Bayesian evolutionary analysis by sampling trees. BMC Evolutionary Biology 7: 214.

Endrödy-Younga, S. (1978) Coleoptera. In Werger, M.J.A. \& van Bruggen, A.C. (Eds) Biogeography and ecology of southern Africa. Dr Wilhelm Junk, The Hague, pp. 799-821.

Endrödy-Younga, S. (1988) Evidence for the low-altitude origin of the Cape mountain biome derived from the systematic revision of the genus Colophon Gray (Coleoptera: Lucanidae). Annals of the South African Museum, Volume 96: part 9.

Excoffier, L. \& Lischer, H.E.L. (2010) Arlequin suite ver. 3.5: A new series of programs to perform population genetics data analyses under Linux and Windows. Molecular Ecology Resources 10: $564-567$.

Farrell, B.D. (2001) Evolutionary assembly of the Milkweed Fauna: Cytochrome Oxidase I and the age of Tetraopes beetles. Molecular Phylogenetics and Evolution 18: 467-478.

Ferguson, J.W.H. (2002) On the use of genetic divergence for identifying species. Biological Journal of the Linnaean Society 75: 509-516.

Forgie, S.A., Philips, T.K., Scholtz, C.H. (2005) Evolution of the Scarabaeini (Scarabaeidae: Scarabaeinae). Systematic Entomology 30, 60-97.

Galley, C. \& Linder, H.P. (2006) Geographical affinities of the Cape flora, South Africa. Journal of Biogeography 33, 236-250.

Geldenhuys, C.J. (1997) Composition and biogeography of forest patches on the inland mountains of the southern Cape. Bothalia 27(1): 57-74.

Herbert, P.D.N., Cywinska, A., Ball, S.L. \& de Waard, J.R. (2003) Biological identification through Barcodes. Proceedings of the Royal Society of London Series B - Biological Sciences 270: $313-321$.

Huson, D.H. \& Bryant, D. (2006) Application of phylogenetic networks in evolutionary studies. Molecular Biology and Evolution 23: 254-267.

Ikeda, H., Nishikawa, M. \& Sota, T. (2012) Loss of flight promotes beetle diversification. Nature Communications 3: 648. 
Juan, C., Oromi, P. \& Hewitt, G.M. (1995) Phylogeny of the genus Hegeter (Tenebrionidae, Coleoptera) and its colonization of the Canary Islands deduced from Cytochrome oxidase I mitochondrial DNA sequences. Proceedings of the Royal Society B: Biological Sciences 261: $173-180$.

Katoh, K \& Toh, H. (2008) Recent developments in the MAFFT multiple sequence alignment program. Briefings in Bioinformatics 9(4): 286-298.

Kück, P. \& Meusemann, K. (2010) FASconCAT: convenient handling of data matrices. Molecular Phylogenetics and Evolution 56: 1115-1118.

Librado, P. \& Rozas, J. (2009) DnaSP v5: a software for comprehensive analysis of DNA polymorphism data. Bioinformatics 25: 1451-1452.

Liedloff, A.C. (1999) Mantel nonparametric test calculator. Version 2.0. School of Natural Resource Sciences, Queensland University of Technology, Australia.

Linder, H.P. (2003) The radiation of the Cape flora, southern Africa. Biological reviews of the Cambridge Philosophical Society Cambridge Philosophical Society 78: 597-638.

Linder, H.P. (2005) Evolution of diversity: the Cape flora. TRENDS in Plant Science 10(11): 536541.

Linder, H.P., Johnson, S.D., Kuhlmann, M., Matthee, C.A., Nyffeler, R. \& Swartz, E.R. (2010) Biotic diversity in the Southern African winter-rainfall region. Current Opinions in Environmental Sustainability 2: 109-116.

Linder, H.P. \& Vlok, J.H.J. (1991) The morphology, taxanomy and evolution of Rhodocoma (Restionaceae). Plant Systematics and Evolution 175: 139-160.

MacDonald, D.E. \& Daniels, S.R. (2012) Phylogeography of the Cape velvet worm (Onychophera: Peripatopsis capensis) reveals the impact of Pliocene/Pleistocene climatic oscillations on Afromontane forest in the Western Cape, South Africa. Journal of Evolutionary Biology 25: $824-835$.

MacLeay, W.S. (1819) Horae entomologicae; or essays on the annulose animals. Containing general observations on the geography, manners, and natural affinities of the Insects which compose the genus Scarabaeus of Linnaeus; o which are added a few incidental remarks on the genera 
Lucanus and Hister of the same author. With an appendix and plates. Vol. 1, Pt. 1. S. Bagster; London. 160 p.

Madeiros, M.J. \& Gillespie, R.G. (2011) Biogeography and the evolution of flightlessness in a radiation of Hawaiian moths (Xyloryctidae: Thyrocopa). Journal of Biogeography 38: 101111

Mantel, N. (1967) Detection of disease clustering and a generalized regression approach. Cancer Research 27: 209-220.

Mayhew, P. J. (2007) Why are there so many insect species? Perspectives from fossils and phylogenies. Biological reviews of the Cambridge Philosophical Society 82: 425-454.

Medina, C.A. \& Scholtz, C.H. (2005) Systematics of the southern African genus Epirinus Reiche (Coleoptera: Scarabaeinae: Canthonini): descriptions of new species and phylogeny. Insect Systematics and Evolution 36: 145-160.

Midley, G.F., Hannah, L., Robertson, R., MacDonald, D.J. \& Allsopp, J. (2001) Have Pleistocene climatic cycles influenced species richness patterns in the Greater Cape Mediterranean Region? Journal of Mediterranean Ecology 2: 137-144.

Mitterboeck, T.F. \& Adamowicz, S.J. (2013) Flight loss linked to faster molecular evolution in insects. Proceedings of the Royal Society B 280: 20131128.

Mucina, L. \& Rutherford, M.C. (2006) The vegetation of South Africa, Lesotho and Swaziland. Strelitzia, 19. South African National Biodiversity Institute, Pretoria.

Myers, N., Mittelmeier, R.A., Mittelmeier, C.G., da Fonseca, G.A.B. \& Kent, J. (2000) Biodiversity hotspots for conservation priorities. Nature 403: 853-858.

Nixon, K.C. \& Wheeler, Q.D. (1990) An amplification of the phylogenetic species concept. Cladistics 6: $211-223$.

Orsini, L., Koivulehto, H. \& Hanski, I. (2007) Molecular evolution and radiation of dung beetles in Madagascar. Cladistics 23: 145-168.

Partridge, T.C., Scott, L. \& Hamilton, J.E. (1999) Synthetic reconstructions of southern African environments during the Last Glacial Maximum (21-18 kyr) and the Holocene Altithermal (86 kyr). Quaternary International 57-58: 207-214. 
Pickford, M. \& Senut, B. (1999) Geology and palaeobiology of the central and southern Namib Desert, southwestern Africa. Geological Survey of Namibia - Memoir 18: 1-155.

Picker, M.D. \& Samways, M.J., 1996. Faunal diversity and endemicity of the Cape Peninsula, South Africa, a first assessment. Biodiversity and Conservation 5: 591-609.

Posada, D. (2008) jModelTest: Phylogenetic Model Averaging. Molecular Biology and Evolution 25(7): 1253-1256.

Price, B.W., Barker, N.P. \& Villet, M.H. (2010) A watershed study on genetic diversity: phylogenetic analysis of the Platypleura plumosa (Hemiptera: Cicadidae) complex reveals catchmentspecific lineages. Molecular Phylogenetics and Evolution 54: 617-626.

Price, B.W., Villet, M.H. \& Barker, N.P. (2007) Patterns and processes underlying evolutionary significant units in the Platypleura stridula L. species complex (Hemiptera: Cicadidae) in the Cape Floristic Region, South Africa. Molecular Ecology 16: 2574-2588.

Rambaut, A. (2009) Figtree v1.3.1. Available from http://tree.bio.ed/ac.uk/software/figtree/.

Rambaut, A. \& Drummond, A.J. (2007) Traces v1.5. Available from http://www.beast.bio.ed.ac.uk/tracer.

Roff, D.A. (1990) The evolution of flightlessness in insects. Ecological Monographs 60 (4): 389-421. Ronquist, F. \& Huelsenbeck, J.P. (2003) MRBAYES 3: Bayesian phylogenetic inference under mixed models. Bioinformatics 19: 1572-1574.

Scholtz, C.H. (1979) The 'horridus'-group of Trox F. species (Coleoptera: Trogidae) in South Africa. Journal of the Entomological Society of southern Africa 42: 169-180.

Scholtz, C.H. (1980) Monograph of the genus Trox F (Coleoptera: Trogidae) of Subsaharan Africa. Cimbebasia Memoir 4: 1-104.

Scholtz, C.H. (1986) Phylogeny and systematics of the Trogidae (Coleoptera: Scarabaeoidea). Systematic Entomology 11: 355-363.

Siesser, W.G. (1980) Late Miocene origin of the Benguela upswelling system off northern Namibia. Science 208: 283-285.

Simon, C., Frati, F., Benckenbach, A., Crespi, B., Liu, H. \& Flook, P. (1994) Evolution, weighting, and phylogenetic utility of mitochondrial gene sequences and a compilation of conserved 
polymerase chain reaction primers. Annals of the Entomological Society of America 87: 652701.

Smith, C.I. \& Farrell, B.D. (2005) Range expansions in the flightless longhorn cactus beetles, Moneilema armatum, in response to Pleistocene climate changes. Molecular Ecology 14: $1025-1044$.

Sole, C.L. \& Scholtz, C.H. (2012) Phylogeographic pointers to conservation needs: South Africa's flagship dung beetle, Circellium bacchus. Insect Conservation and Diversity 6(5): 549-560.

Sole, C.L., Scholtz, C.H., \& Bastos, A.D.S. (2005) Phylogeography of the Namib Desert dung beetles Scarabaeus (Pachysoma) MacLeay (Coleoptera: Scarabaeidae). Journal of Biogeography 32: 75-84.

Stamatakis, A., Blagojevic, F., Nikolopoulos, D. \& Antonopoulos, C. (2007) Exploring new search algorithms and hardware for phylogenetics: RAxML meets the IBM cell. Journal of VLSI Signal Processing-Systems for Signal Image and Video Technology 48: 271-286.

Stamatakis, A. (2014) RAxML version 8: A tool for phylogenetic analysis and post-analysis of large phylogenies. Bioinformatics 30(9): 1312-1313.

Stuckenberg, R. (1962) The distribution of the montane palaeogenic elements in the South African invertebrate fauna. Annals of the Cape Provincial Museum 2: 190-205.

Strümpher, W.P., Sole, C.L., Villet, M.H. \& Scholtz, C.H. (2014) Phylogeny of the family Trogidae (Coleoptera: Scarabaeoidea) inferred from mitochondrial and nuclear ribosomal DNA sequence data. Systematic Entomology 39(3): 548-562. doi: 10.1111/syen.12074.

Strümpher, W.P., Villet, M.H., Sole, C.L. \& Scholtz, C.H. (2015) Overview and revision of the extant genera and subgenera of Trogidae (Coleoptera: Scarabaeoidea). Insect Systematics and Evolution. doi: 10.1163/1876312X-46052133

Swart, B.L., Tolley, K.A. \& Matthee, C.A. (2009) Climate change drives speciation in the southern rock agama (Agama atra) in the Cape Floristic Region, South Africa. Journal of Biogeography 36: 78-87. 
Switala, A.K., Sole, C.L., \& Scholtz, C.H., 2014. Phylogeny, historical biogeography and divergence time estimates of the genus Colophon Gray (Coleoptera: Lucanidae). Invertebrate Systematics 28(3): 326-336.

Swofford, D.L. (2003) PAUP*: Phylogenetic analysis using parsimony (* and other methods), Version 4. Sinauer Associates, Sunderland, MA, United States.

Tamura, K., Stecher, G., Peterson, D., Filipski, A. \& Kumar, S. (2013) MEGA6: Molecular Evolutionary Genetics Analysis version 6.0. Molecular Biology and Evolution 30: 27252729.

Tolley, K.A., Burger, M., Turner, A.A. \& Matthee, C.A. (2006) Biogeographic patterns and phylogeography of dwarf chameleons (Brachypodion) in an African biodiversity hotspot. Molecular Ecology 15: 781-793.

Voje, K.L., Hemp, C., Flagstad, O., Saeter, G-P. \& Stenseth, N. (2009) Climate change as an engine for speciation in flightless Orthoptera species inhabiting African mountains. Molecular Ecology 18: 93-108.

Wagner, D.L., Liebherr, J.K., 1992. Flightlessness in insects. Trends in Ecology and Evolution 7(7): 216-220.

Wheeler, Q. \& Platnick, N. (2000) The phylogenetic species concept (sensu Wheeler and Platnick), pp 55-69. In, Wheeler, Q.D. and R. Meier (editors), Species Concepts and Phylogenetic Theory: A Debate. Columbia University Press, New York. 230 pp.

Wirta. H., Orsini, L. \& Hanski, I. (2008) An old adaptive radiation of forest dung beetles in Madagascar. Molecular Phylogenetics and Evolution 47: 1076-1089. 


\section{Appendix}

Table A1. List of taxa and collection data of trogid beetles used in this study.

\begin{tabular}{|c|c|c|c|c|}
\hline Species & Locality data & Code & $16 \mathrm{~S}$ & $\mathrm{CO} 1$ \\
\hline \multicolumn{5}{|l|}{ Outgroup } \\
\hline Phoberus nasutus & $\begin{array}{l}\text { RSA: Western Cape Prov., near Simonstown, 07.IX.2008, S34.22200 E18.41069, 80m, C. } \\
\text { Deschodt (UPSA) }\end{array}$ & TnST01 & KC801097* & $\mathrm{Y}$ \\
\hline P. nasutus & $\begin{array}{l}\text { RSA: Western Cape Prov., near Simons Town, 07.IX.2008, S34.22200 E18.41069, 80m, C. } \\
\text { Deschodt (UPSA) }\end{array}$ & TnST02 & KC801096* & $\mathrm{Y}$ \\
\hline P. nasutus & $\begin{array}{l}\text { RSA: Western Cape Prov., near Simons Town, 07.IX.2008, S34.22200 E18.41069, 80m, C. } \\
\text { Deschodt (UPSA) }\end{array}$ & TnST03 & $\mathrm{Y}$ & $\mathrm{Y}$ \\
\hline
\end{tabular}

Ingroup

Phoberus capensis

P. capensis

P. capensis
RSA: Western Cape Prov., Moordenaarskop, 940m, 15.XII.2007, S34.09809 E18.96465º, WP Strümpher (UPSA)

RSA: Western Cape Prov., Moordenaarskop, 940m, 15.XII.2007, S34.09809 E18.96465 ${ }^{\circ}$ WP Strümpher (UPSA)

RSA: Western Cape Prov., Sneeukop, S34.03919² E18.99026º 1300m, 18.XII.2007, WP. Strümpher (UPSA)
CMK02 Y

$\mathrm{Y}$

CMK05 X

Y

CSn01 Y 


\begin{tabular}{|c|c|c|c|c|}
\hline Species & Locality data & Code & $16 \mathrm{~S}$ & $\mathrm{CO} 1$ \\
\hline P. capensis & $\begin{array}{l}\text { RSA: Western Cape Prov., Sneeukop, S34.03919 E18.99026º } 1300 \mathrm{~m}, 18 . \text { XII.2007, WP. } \\
\text { Strümpher (UPSA) }\end{array}$ & $\mathrm{CSn} 02$ & $\mathrm{Y}$ & $\mathrm{Y}$ \\
\hline P. capensis & $\begin{array}{l}\text { RSA: Western Cape Prov., Sneeukop, S34.03919 E18.99026 }{ }^{\circ} 1300 \mathrm{~m}, 18 . X I I .2007, \text { WP. } \\
\text { Strümpher (UPSA) }\end{array}$ & CSn04 & $\mathrm{Y}$ & $\mathrm{Y}$ \\
\hline P. capensis & 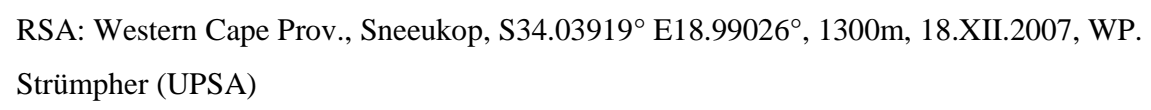 & CSn06 & $\mathrm{X}$ & $\mathrm{Y}$ \\
\hline P. capensis & $\begin{array}{l}\text { RSA: Western Cape Prov., Sneeukop, S34.03919 E18.99026 }{ }^{\circ} \text { 1300m, 18.XII.2007, WP. } \\
\text { Strümpher (UPSA) }\end{array}$ & $\mathrm{CSn} 07$ & $\mathrm{X}$ & $\mathrm{Y}$ \\
\hline P. capensis & $\begin{array}{l}\text { RSA: Western Cape Prov., Sneeukop, S34.03919 E18.99026 }{ }^{\circ} \text { 1300m, 18.XII.2007, WP. } \\
\text { Strümpher (UPSA) }\end{array}$ & $\mathrm{CSn} 08$ & $\mathrm{X}$ & $\mathrm{Y}$ \\
\hline P. capensis & 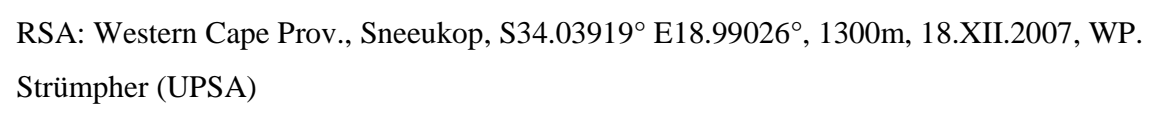 & CSn09 & $\mathrm{Y}$ & $\mathrm{Y}$ \\
\hline P. capensis & 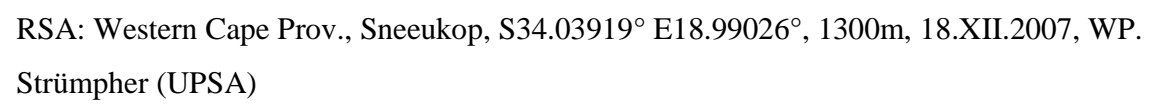 & CSn 10 & $\mathrm{Y}$ & $\mathrm{Y}$ \\
\hline P. capensis & $\begin{array}{l}\text { RSA: Western Cape Prov., Sneeukop, S34.03919 E18.99026 }{ }^{\circ} 1300 \mathrm{~m}, 18 . X I I .2007, \text { WP. } \\
\text { Strümpher (UPSA) }\end{array}$ & CSn11 & $\mathrm{X}$ & $\mathrm{Y}$ \\
\hline P. capensis & $\begin{array}{l}\text { RSA: Western Cape Prov., Sneeukop, S34.03919 E18.99026 }{ }^{\circ} 1300 \mathrm{~m}, 18 . X I I .2007, \text { WP. } \\
\text { Strümpher (UPSA) }\end{array}$ & CSn12 & $\mathrm{Y}$ & $\mathrm{Y}$ \\
\hline P. capensis & 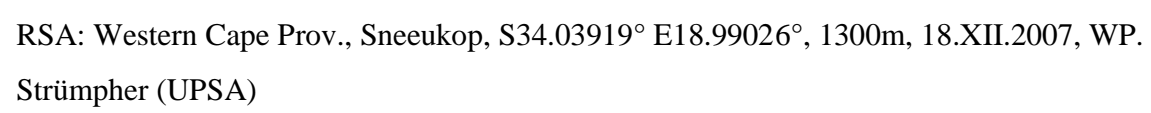 & CSn 13 & $\mathrm{Y}$ & $\mathrm{Y}$ \\
\hline P. capensis & $\begin{array}{l}\text { RSA: Western Cape Prov., Sneeukop, S34.03919 E18.99026ํ․ 1300m, 18.XII.2007, WP. } \\
\text { Strümpher (UPSA) }\end{array}$ & CSn 15 & $\mathrm{X}$ & $\mathrm{Y}$ \\
\hline
\end{tabular}




\begin{tabular}{|c|c|c|c|c|}
\hline Species & Locality data & Code & $16 \mathrm{~S}$ & $\mathrm{CO} 1$ \\
\hline P. capensis & $\begin{array}{l}\text { RSA: Western Cape Prov., Sneeukop, S34.03919² E18.99026º 1300m, 18.XII.2007, WP. } \\
\text { Strümpher (UPSA) }\end{array}$ & CSn20 & $\mathrm{Y}$ & $\mathrm{Y}$ \\
\hline P. capensis & $\begin{array}{l}\text { RSA: Eastern Cape Prov., Grahamstown, Signal Hill, 620m, S33²0'07" E26³2'50", 03.IX.2008, } \\
\text { WP. Strümpher (UPSA) }\end{array}$ & CGt01 & $\mathrm{X}$ & $\mathrm{Y}$ \\
\hline P. capensis & $\begin{array}{l}\text { RSA: Eastern Cape Prov., Grahamstown, Signal Hill, 620m, S33²0'07" E26³2'50", 03.IX.2008, } \\
\text { WP. Strümpher (UPSA) }\end{array}$ & CGt02 & $\mathrm{Y}$ & $\mathrm{Y}$ \\
\hline Phoberus disjunctus sp. $\mathrm{n}$. & $\begin{array}{l}\text { RSA: Western Cape Prov., Matroosberg, 1880m, S33²2'22" E19³9'34", 22.XI.2010, CH. Scholtz } \\
\text { (UPSA) }\end{array}$ & MtB01 & $\mathrm{Y}$ & $\mathrm{Y}$ \\
\hline P. disjunctus sp. n. & $\begin{array}{l}\text { RSA: Western Cape Prov., Matroosberg, 1880m, S33²2'22" E19³9'34", 22.XI.2010, CH. Scholtz } \\
\text { (UPSA) }\end{array}$ & MtB02 & $\mathrm{Y}$ & $\mathrm{Y}$ \\
\hline P. disjunctus sp. n. & $\begin{array}{l}\text { RSA: Western Cape Prov., Matroosberg, 1880m, S33²2'22" E19³9'34", 22.XI.2010, CH. Scholtz } \\
\text { (UPSA) }\end{array}$ & MtB03 & $\mathrm{Y}$ & Y \\
\hline P. disjunctus sp. n. & $\begin{array}{l}\text { RSA: Western Cape Prov., Matroosberg, 1880m, S33²2'22" E19³9'34", 22.XI.2010, CH. Scholtz } \\
\text { (UPSA) }\end{array}$ & MtB04 & $\mathrm{Y}$ & $\mathrm{Y}$ \\
\hline P. disjunctus sp. n. & $\begin{array}{l}\text { RSA: Western Cape Prov., Swartberg Pass, 1510m, S33²0'59" E22¹5'52", 15.XI.2011, WP. } \\
\text { Strümpher \& CH. Scholtz (UPSA) }\end{array}$ & SBP01 & $\mathrm{Y}$ & $\mathrm{Y}$ \\
\hline P. disjunctus sp. n. & $\begin{array}{l}\text { RSA: Western Cape Prov., Swartberg Pass, 1510m, S33²0'59" E22¹5'52", 15.XI.2011, WP. } \\
\text { Strümpher \& CH. Scholtz (UPSA) }\end{array}$ & SBP02 & $\mathrm{Y}$ & Y \\
\hline P. disjunctus sp. $\mathrm{n}$. & $\begin{array}{l}\text { RSA: Western Cape Prov., Swartberg Pass, 1510m, S33²0'59" E22²15'52", 15.XI.2011, WP. } \\
\text { Strümpher \& CH. Scholtz (UPSA) }\end{array}$ & SBP03 & $\mathrm{Y}$ & $\mathrm{Y}$ \\
\hline P. disjunctus sp. n. & $\begin{array}{l}\text { RSA: Western Cape Prov., Swartberg Pass, 1510m, S33²0'59" E22¹5'52", 15.XI.2011, WP. } \\
\text { Strümpher \& CH. Scholtz (UPSA) }\end{array}$ & SBP04 & $\mathrm{Y}$ & $\mathrm{Y}$ \\
\hline
\end{tabular}




\begin{tabular}{|c|c|c|c|c|}
\hline Species & Locality data & Code & $16 \mathrm{~S}$ & $\mathrm{CO} 1$ \\
\hline P. disjunctus sp. $\mathrm{n}$. & $\begin{array}{l}\text { RSA: Western Cape Prov., Swartberg Pass, 1510m, S33²0'59" E22¹5'52", 15.XI.2011, WP. } \\
\text { Strümpher \& CH. Scholtz (UPSA) }\end{array}$ & SBP05 & $\mathrm{Y}$ & $\mathrm{Y}$ \\
\hline P. disjunctus sp. $\mathrm{n}$. & $\begin{array}{l}\text { RSA: Western Cape Prov., Swartberg Pass, 1510m, S33²0'59" E22'15'52", 15.XI.2011, WP. } \\
\text { Strümpher \& CH. Scholtz (UPSA) }\end{array}$ & SBP06 & $\mathrm{X}$ & $\mathrm{Y}$ \\
\hline P. disjunctus sp. n. & $\begin{array}{l}\text { RSA: Western Cape Prov., Cederberg Conservancy, 1547m, S32²4'22" E1904'50", 12.XII.2011, } \\
\text { WP. Strümpher \& CH. Scholtz (UPSA) }\end{array}$ & CDB01 & $\mathrm{Y}$ & $\mathrm{Y}$ \\
\hline Phoberus herminae sp. $\mathrm{n}$. & $\begin{array}{l}\text { RSA: Western Cape Prov., Outeniqua Mountains, Outeniqua Pass, } 668 \mathrm{~m}, \mathrm{~S} 33.90000^{\circ} \mathrm{E} 22.40107^{\circ} \text {, } \\
\text { 25.XII.2007, C Deschodt (UPSA) }\end{array}$ & COP01 & $\mathrm{Y}$ & $\mathrm{Y}$ \\
\hline P. herminae sp. n. & $\begin{array}{l}\text { RSA: Western Cape Prov., Outeniqua Mountains, Outeniqua Pass, } 668 \mathrm{~m}, \mathrm{~S} 33.90000^{\circ} \text { E22.40107², } \\
\text { 25.XII.2007, C Deschodt (UPSA) }\end{array}$ & COP02 & $\mathrm{Y}$ & $\mathrm{Y}$ \\
\hline P. herminae sp. n. & $\begin{array}{l}\text { RSA: Western Cape Prov., Outeniqua Mountains, Outeniqua Pass, } 668 \mathrm{~m}, \mathrm{~S} 33.90000^{\circ} \text { E22. } 40107^{\circ} \text {, } \\
\text { 25.XII.2007, C Deschodt (UPSA) }\end{array}$ & COP03 & $\mathrm{Y}$ & $\mathrm{Y}$ \\
\hline P. herminae sp. n. & $\begin{array}{l}\text { RSA: Eastern Cape Prov., Langeberge, Ruiterbos, 800m, S3352'31" E2201'22", 15.XI.2004, C. } \\
\text { Deschodt (UPSA) }\end{array}$ & $\mathrm{CRb} 01$ & $\mathrm{Y}$ & $\mathrm{Y}$ \\
\hline P. herminae sp. $\mathrm{n}$. & 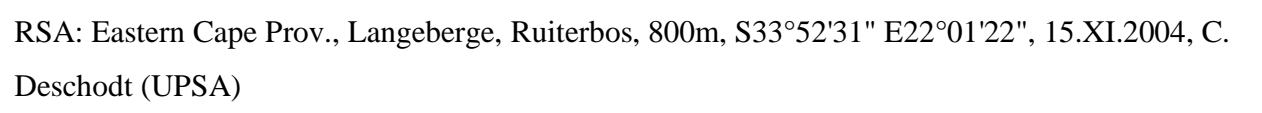 & 76 & $\mathrm{Y}$ & $\mathrm{Y}$ \\
\hline P. herminae sp. n. & $\begin{array}{l}\text { RSA: Eastern Cape Prov., Langeberge, Ruiterbos, 800m, S3352'31" E22º1'22", 15.XI.2004, C. } \\
\text { Deschodt (UPSA) }\end{array}$ & $80 \mathrm{~A}$ & $\mathrm{Y}$ & $\mathrm{Y}$ \\
\hline P. herminae sp. n. & 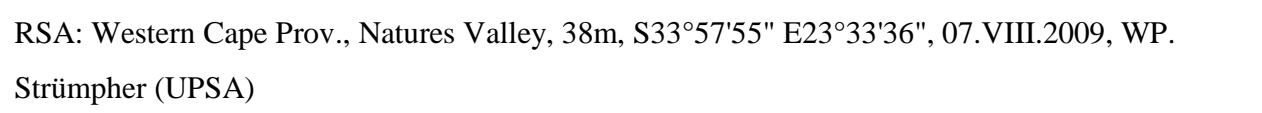 & CNV02 & $\mathrm{Y}$ & $\mathrm{Y}$ \\
\hline P. herminae sp. n. & $\begin{array}{l}\text { RSA: Western Cape Prov., Natures Valley, 40m, 3358'02" E2333'36", 02.VII.2004, C. Deschodt } \\
\text { (UPSA) }\end{array}$ & 108B & $\mathrm{Y}$ & $\mathrm{Y}$ \\
\hline
\end{tabular}




\begin{tabular}{|c|c|c|c|c|}
\hline Species & Locality data & Code & $16 \mathrm{~S}$ & $\mathrm{CO} 1$ \\
\hline P. herminae sp. n. & $\begin{array}{l}\text { RSA: Western Cape Prov., Diepwalle Forest, } 4 \text { 30m, S3357'40" E2309'22", 15.VI.2003, C. } \\
\text { Deschodt (UPSA) }\end{array}$ & $\mathrm{CKn} 03$ & $\mathrm{X}$ & $\bar{Y}$ \\
\hline P. herminae sp. n. & $\begin{array}{l}\text { RSA: Western Cape Prov., Diepwalle Forest, } 4 \text { 30m, S3357'40" E230'ㄹ'22", 15.VI.2003, C. } \\
\text { Deschodt (UPSA) }\end{array}$ & $59 \mathrm{~B}$ & $\mathrm{X}$ & $\mathrm{Y}$ \\
\hline P. herminae sp. n. & 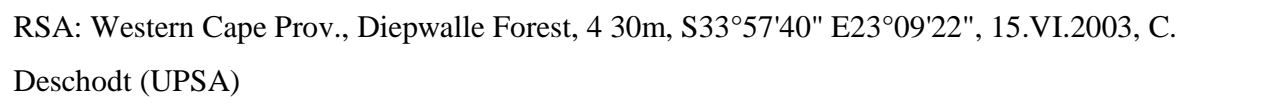 & $59 \mathrm{C}$ & $\mathrm{X}$ & $\mathrm{Y}$ \\
\hline P. herminae sp. n. & $\begin{array}{l}\text { RSA: Western Cape Prov., Buffalo Valley, 81m, S3359'29" E } 23^{\circ} 17^{\prime} 55^{\prime \prime}, 02 . \text { VII.2004, C. Deschodt } \\
\text { (UPSA) }\end{array}$ & 109B & $\mathrm{X}$ & $\mathrm{Y}$ \\
\hline P. herminae sp. n. & $\begin{array}{l}\text { RSA: Western Cape Prov., Buffalo Valley, 118m, S3358'56" E 23¹8'06", 02.VII.2004, C. } \\
\text { Deschodt (UPSA) }\end{array}$ & $110 \mathrm{~A}$ & $\mathrm{X}$ & $\mathrm{Y}$ \\
\hline P. herminae sp. n. & $\begin{array}{l}\text { RSA: Western Cape Prov., Buffalo Valley, 118m, S3358'56" E 23¹8'06", 02.VII.2004, C. } \\
\text { Deschodt (UPSA) }\end{array}$ & 110B & $\mathrm{Y}$ & $\mathrm{Y}$ \\
\hline P. herminae sp. n. & 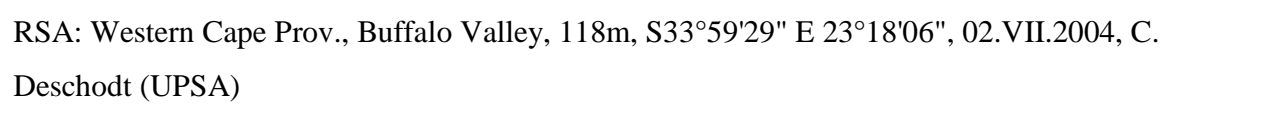 & $110 \mathrm{C}$ & $\mathrm{Y}$ & $\mathrm{Y}$ \\
\hline P. herminae sp. n. & 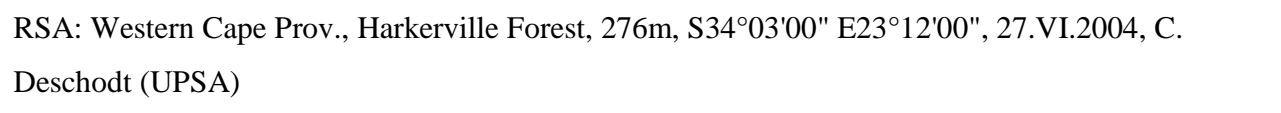 & $106 \mathrm{~A}$ & $\mathrm{X}$ & $\mathrm{Y}$ \\
\hline P. herminae sp. n. & 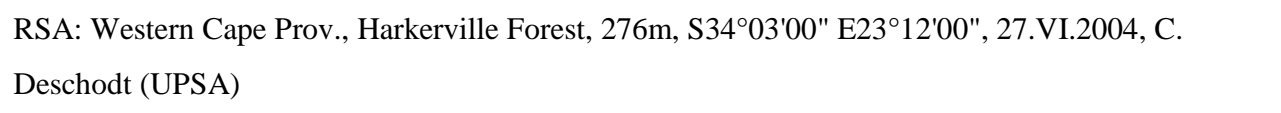 & 106B & $\mathrm{Y}$ & $\mathrm{Y}$ \\
\hline P. herminae sp. $\mathrm{n}$. & 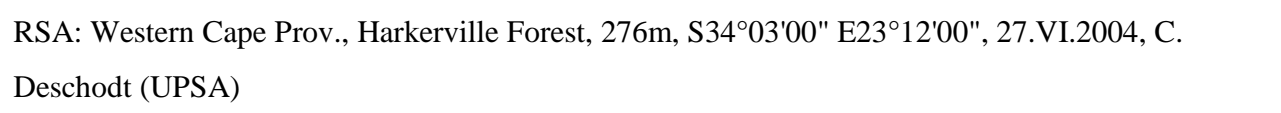 & $106 \mathrm{C}$ & $\mathrm{Y}$ & $\mathrm{Y}$ \\
\hline P. herminae sp. n. & 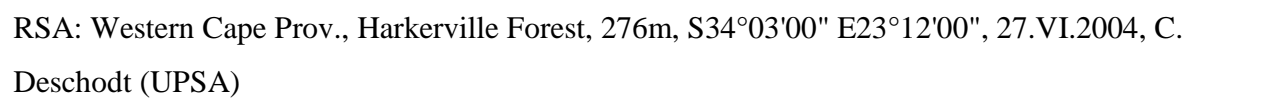 & $106 \mathrm{D}$ & $\mathrm{X}$ & $\mathrm{Y}$ \\
\hline
\end{tabular}




\begin{tabular}{|c|c|c|c|c|}
\hline Species & Locality data & Code & $16 \mathrm{~S}$ & $\mathrm{CO} 1$ \\
\hline P. herminae sp. $\mathrm{n}$. & $\begin{array}{l}\text { RSA: Western Cape Prov., Harkerville Forest, 276m, S3403'00" E2312'00", 27.VI.2004, C. } \\
\text { Deschodt (UPSA) }\end{array}$ & $107 \mathrm{~A}$ & $\mathrm{Y}$ & $\mathrm{Y}$ \\
\hline P. herminae sp. n. & $\begin{array}{l}\text { RSA: Western Cape Prov., Harkerville Forest, } 276 \mathrm{~m}, \mathrm{~S} 34^{\circ} 03^{\prime} 00^{\prime \prime} \mathrm{E} 23^{\circ} 12^{\prime} 00^{\prime \prime}, 27 . \mathrm{VI} .2004, \mathrm{C} \text {. } \\
\text { Deschodt (UPSA) }\end{array}$ & 107B & $\mathrm{Y}$ & $\mathrm{Y}$ \\
\hline P. herminae sp. n. & $\begin{array}{l}\text { RSA: Western Cape Prov., Harkerville Forest, } 276 \mathrm{~m}, \mathrm{~S} 34^{\circ} 03^{\prime} 00^{\prime \prime} \mathrm{E} 23^{\circ} 12^{\prime} 00^{\prime \prime}, 27 . \mathrm{VI} .2004, \mathrm{C} . \\
\text { Deschodt (UPSA) }\end{array}$ & $107 \mathrm{C}$ & $\mathrm{Y}$ & $\mathrm{Y}$ \\
\hline P. herminae sp. n. & $\begin{array}{l}\text { RSA: Western Cape Prov., Harkerville Forest, } 276 \mathrm{~m}, \mathrm{~S} 34^{\circ} 03^{\prime} 00^{\prime \prime} \mathrm{E} 23^{\circ} 12^{\prime} 00^{\prime \prime}, 27 . \mathrm{VI} .2004, \mathrm{C} \text {. } \\
\text { Deschodt (UPSA) }\end{array}$ & $107 \mathrm{D}$ & $\mathrm{Y}$ & $\mathrm{Y}$ \\
\hline P. herminae sp. n. & $\begin{array}{l}\text { RSA: Western Cape Prov., Harkerville Forest, } 276 \mathrm{~m}, \mathrm{~S}^{\circ} 04^{\circ} 03^{\prime} 00^{\prime \prime} \mathrm{E} 23^{\circ} 12^{\prime} 00^{\prime \prime}, 27 . \mathrm{VI} .2004, \mathrm{C} \text {. } \\
\text { Deschodt (UPSA) }\end{array}$ & $107 \mathrm{E}$ & $\mathrm{Y}$ & $\mathrm{Y}$ \\
\hline P. herminae sp. n. & RSA: Western Cape Prov., Stormsrivier. December, 2005 (UPSA) & 111 & $\mathrm{Y}$ & $\mathrm{Y}$ \\
\hline
\end{tabular}

Y indicates PCR amplification successful, X indicates PCR amplification failed. UPSA, depository for molecular voucher. * Sequences generated by Strümpher et al. (2014). 
Table A2. GenBank accession numbers for the COI haplotypes of Phoberus capensis, P. disjunctus sp. n., P. herminae sp. n. and P. nasutus

\begin{tabular}{|c|c|c|c|c|}
\hline Species & Population/Locality & Haplotype & Individuals & GenBank accession No. \\
\hline \multirow[t]{10}{*}{ Phoberus capensis } & Sneeukop / Moordenaarskop & TCAA01 & $\begin{array}{l}\text { CSn01, CSn02, CSn04, CSn06, CSn07, } \\
\text { CSn08, CSn15, CMK05 }\end{array}$ & KT075105 \\
\hline & Moordenaarskop & TCAA02 & CMK02 & KT075106 \\
\hline & Sneeukop & TCAA03 & $\mathrm{CSn} 20$ & KT075107 \\
\hline & Sneeukop & TCAA04 & CSn11 & КT075108 \\
\hline & Sneeukop & TCAA05 & CSn13 & KT075109 \\
\hline & Sneeukop & TCAA06 & CSn10 & KT075110 \\
\hline & Sneeukop & TCAA07 & CSn09 & KT075111 \\
\hline & Sneeukop & TCAA08 & CSn12 & KT075112 \\
\hline & Grahamstown & TCAA09 & CGt02 & KT075113 \\
\hline & Grahamstown & TCAA10 & CGt01 & KT075114 \\
\hline \multirow[t]{5}{*}{ Phoberus disjunctus sp. $\mathrm{n}$. } & Cederberg & TCBA01 & CDB01 & KT075115 \\
\hline & Matroosberg & TCBA02 & MtB01 & KT075116 \\
\hline & Matroosberg & TCBA03 & MtB02 & KT075117 \\
\hline & Matroosberg & TCBA04 & MtB03, MtB04 & KT075118 \\
\hline & Swartberg Pass & TCBA05 & SBP01 & KT075119 \\
\hline
\end{tabular}




\begin{tabular}{|c|c|c|c|c|}
\hline & Swartberg Pass & TCBA06 & SBP02 & KT075120 \\
\hline & Swartberg Pass & TCBA07 & SBP04 & KT075121 \\
\hline & Swartberg Pass & TCBA08 & SBP05, SBP06 & KT075122 \\
\hline & Swartberg Pass & TCBA09 & SBP03 & KT075123 \\
\hline Phoberus herminae sp. $\mathrm{n}$. & Outeniqua Pass & TCCA01 & COP01 & KT075124 \\
\hline & Ruiterbos & TCCA02 & 76, 80A, CRb01 & KT075125 \\
\hline & Knysna & TCCA03 & 109B, 110A, 110B, 110C & KT075126 \\
\hline & Outeniqua Pass & TCCA04 & $\mathrm{COP} 02$ & KT075127 \\
\hline & Outeniqua Pass & TCCA05 & COP03 & KT075128 \\
\hline & Knysna & TCCA06 & 107A, 107B, 107E, 106C, 106D & KT075129 \\
\hline & Knysna & TCCA07 & 106B & KT075130 \\
\hline & Knysna & TCCA08 & 108B & KT075131 \\
\hline & Knysna & TCCA09 & 59C, CKn03 & KT075132 \\
\hline & Knysna & TCCA10 & $106 \mathrm{~A}, 59 \mathrm{~B}$ & КT075133 \\
\hline & Knysna & TCCA11 & $107 \mathrm{C}, 107 \mathrm{D}$ & KT075134 \\
\hline & Tsitsikama & TCCA12 & CNV02 & КT075135 \\
\hline & Stormsrivier & TCCA12 & 111 & KT075136 \\
\hline
\end{tabular}


Table A3. GenBank accession number for the $16 \mathrm{~S}$ haplotypes of Phoberus capensis, $P$. disjunctus sp. n. and $P$. herminae sp. n. * $=$ Sequences generated by Strümpher et al. (2014).

\begin{tabular}{|c|c|c|c|c|}
\hline Species & Population/Locality & Haplotype & Individuals & GenBank accession \# \\
\hline \multirow[t]{2}{*}{ Phoberus capensis } & Sneeukop / Moordenaarskop & TCAB01 & $\begin{array}{l}\text { CSn01, CSn02, CSn04, CSn10, CSn12, } \\
\text { CSn13, CSn20 }\end{array}$ & KT008923 \\
\hline & Grahamstown & TCAB02 & CGt02 & KT008924 \\
\hline \multirow[t]{5}{*}{ Phoberus disjunctus sp. $\mathrm{n}$. } & Cederberg / Matroosberg & TCBB05 & CDB01, MtB03, MtB04 & KT008929 \\
\hline & Matroosberg & TCBB04 & MtB01, MtB02 & KT008928 \\
\hline & Swartberg Pass & TCBB01 & SBP01, SBP02 & KT008925 \\
\hline & Swartberg Pass & TCBB02 & SBP03 & KT008926 \\
\hline & Swartberg Pass & TCBB03 & SBP04, SBP05 & KT008927 \\
\hline \multirow[t]{2}{*}{ Phoberus herminae sp. $\mathrm{n}$. } & Knysna & TCCB01 & $107 \mathrm{~A}, 107 \mathrm{~B}, 107 \mathrm{C}, 107 \mathrm{E}, 106 \mathrm{~B}, 106 \mathrm{C}$ & KT008930 \\
\hline & Stormsrivier & TCCB03 & 111 & KT008932 \\
\hline \multirow[t]{2}{*}{ Phoberus nasutus } & Cape Peninsula & & TnST01 & KC $801097 *$ \\
\hline & & & TnST02 & KC801096* \\
\hline
\end{tabular}


Figure A1. The strict consensus Parsimony tree.

\section{Populations}

- Sneeukop Moordenaarskop

- Grahamstown

- - Swartberg Pass

-Matroosberg

- Cederberg

D-Knysna/Tsitsikama/Ruiterbos Outeniqua Pass/Stormsriver

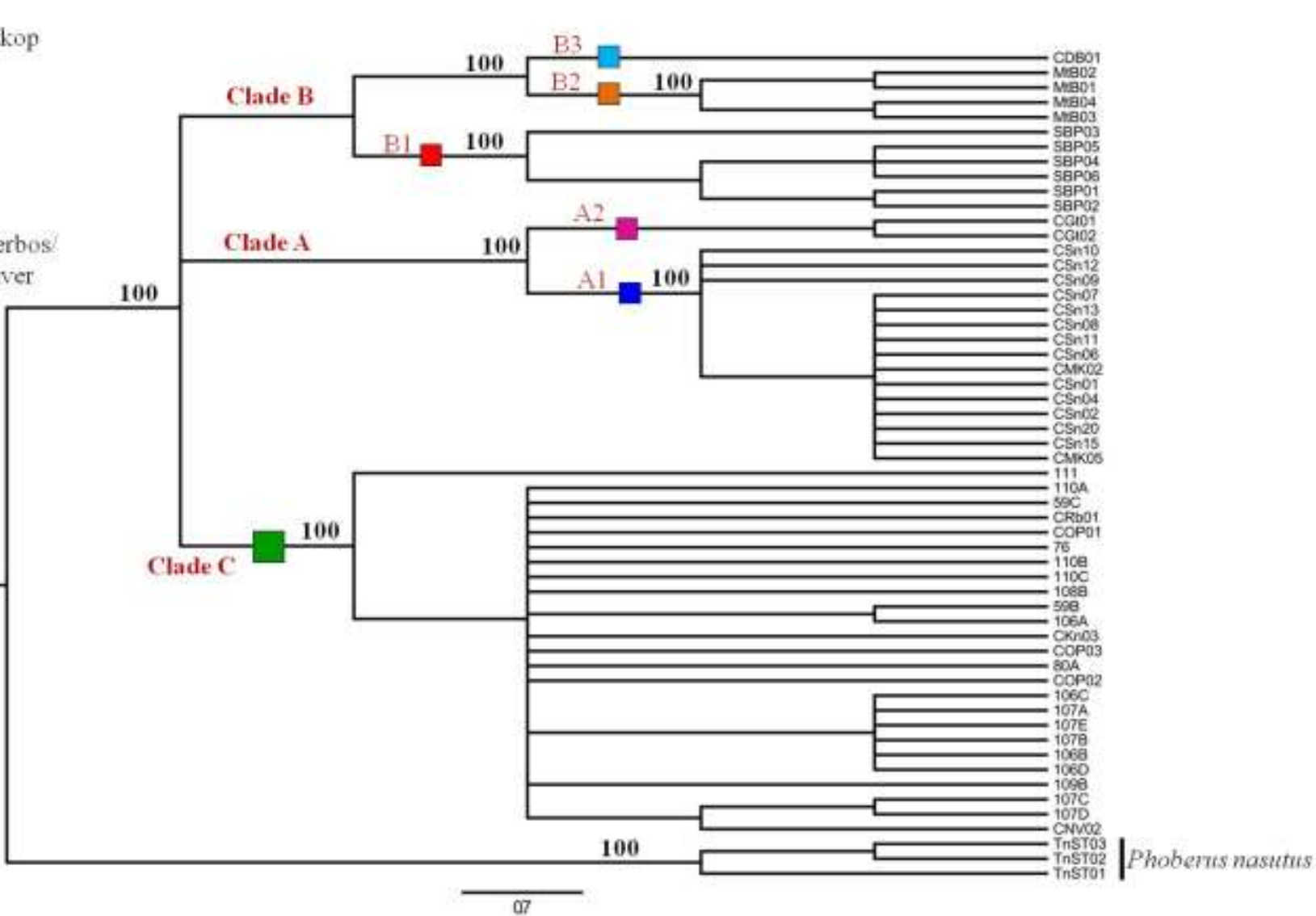

